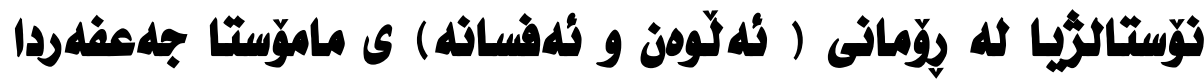

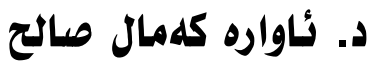

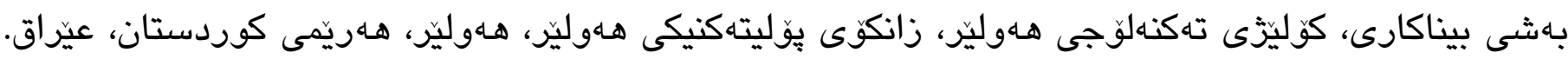
ئيميل: awara.saleh@epu.edu.iq

نوّستالزيا ياخود سوّز و حهسرهت بو سهردهمى رِابردوو، يهكيكه لهو دياردانهى كه له نيّو بهرهامى نووساراندا رهنكيداوهتهوه. ئهويش كاتيك تاكى نووسهار له زيّدى خوّى دادهبريت و له جوكرافيايهكى ديكهدا دهكيرسيتهوه، ئيدى ساتهكانى رِابردوو هزرى تاكى نووسهار دادهريت. نووسهارى تاراوكَنشين لهم حالّتهدا

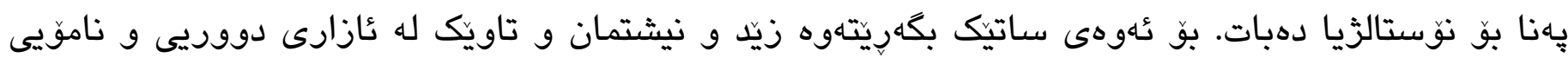

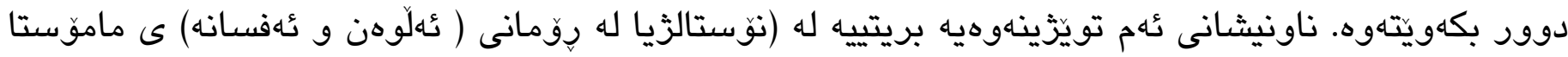

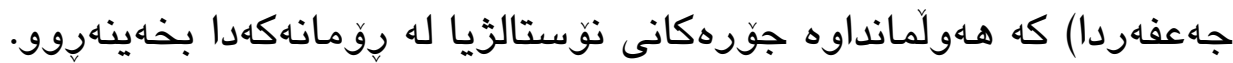

ناوهووكى تويّزينهوهكه له يِيشاكى و دوو تهوهر يِيكهاتووه، تهوهرى يهكهم دوو لايهن له خو دهكريّت كه

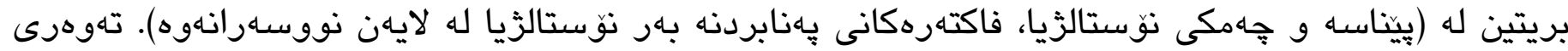

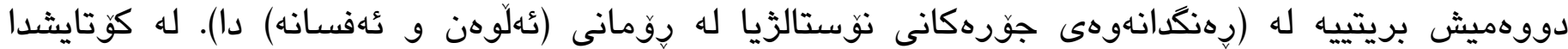

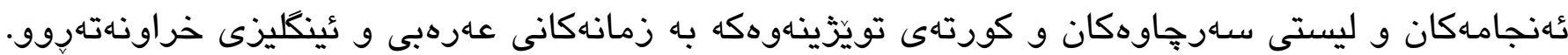
كليله وشُكان: نوستالزيا، رِابردوو، دابِان ، تاراوكَ، ناموّيى، زيدّ و نيشتمان. 
نوّستالزيا دياردهيهكه له لاى زوّبهى تاكهكانى كومهلكَهدا هـيه، بهلاّم كاريكهريى و دهركهوتهكانى له

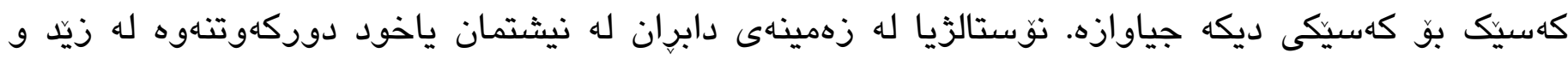

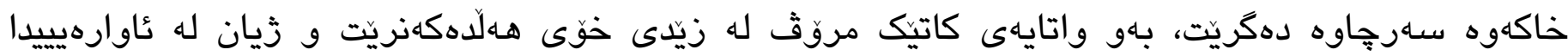

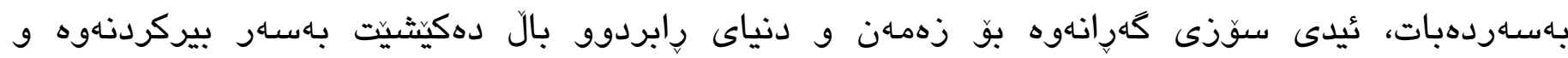

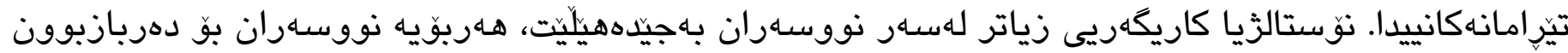

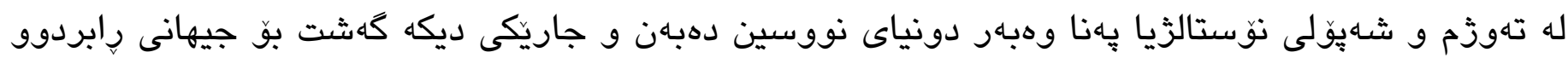

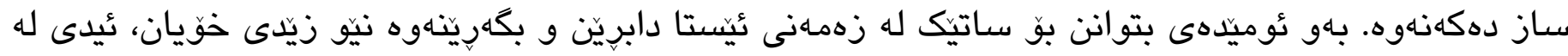

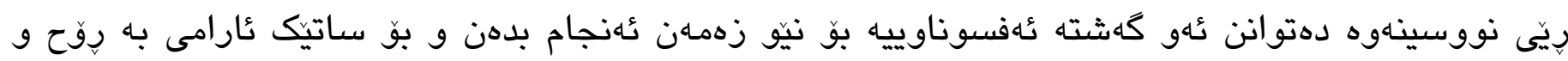
دروونيان ببهخشن.

ناونيشانى ئهم تويَّينهوهيه بريتييه له (نوّستالزيا له روّمانى (ئهلوهن و ئهفسانه) ى ماموّستا جهعفهردا)،

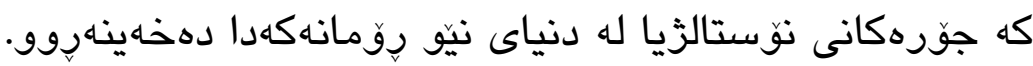
له تويَزينهوهكها بِهيرهوى رِيِّازى (وهسفى شيكارى) بو كَهيشتن به ئهنجامهكان كراوه. ناوهروكى تويّزينهوهكه له يِيشهكى و دوو تهوهر يِيكهاتووه، تهوهرى يهكهم ئهم لايهنانه له خو دهكريت

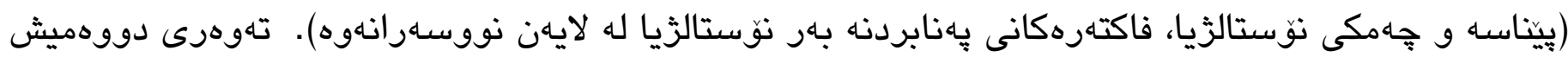

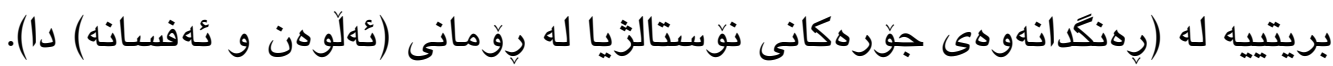

له كوتايشدا ئهنجامهكان و ليستى سهرجاوهكان و كورتهى تويَزينهوهكه به زمانهانى عهرهبى و ئينكليزى

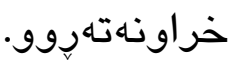

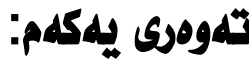

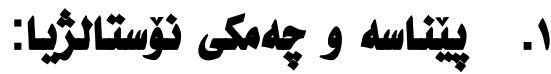

نوستالزيا وهكو دياردهيهك زياتر له حالّتى دابران و دووركهوتنهوه له نيشتمان سهرههلّدهات و كهشه

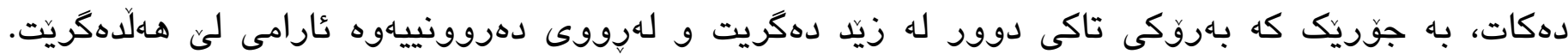

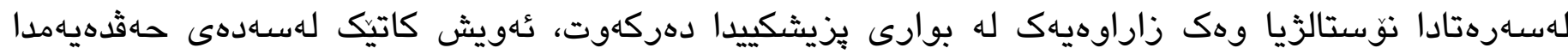
قوتابييهكى كوليزّيى بزيشكى له زانكوى (بازلى سويسرا) به ناوى (يوهانس هوَفر) زاراوهى نوّستالزياى وهكو

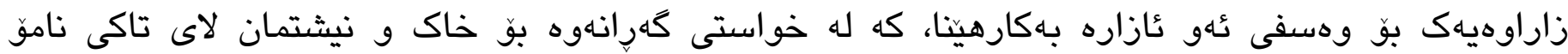

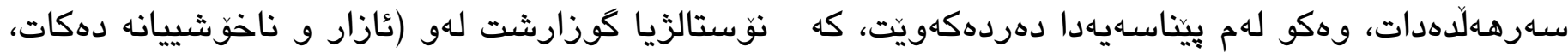




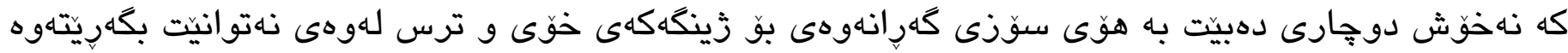

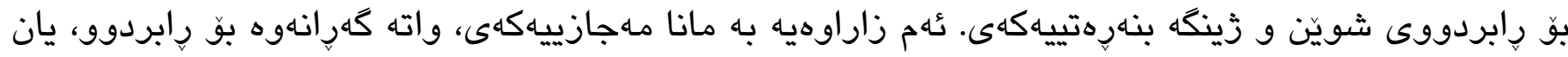

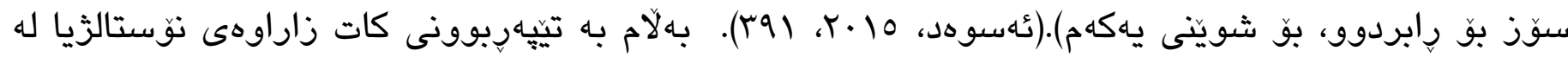
بوارى يزيشكيهوه يهإييهوه و وهكو دياردهيهك بو كوزارشتكردن له حالهتيكى شيعريى لاى شاعيران و نووسـاران خوّى بينييهوه. نوستالزيا له دوو وشـهى يوّنانى كؤن يِيكهاتووه، كه بريتين له (Nostos) بهماناى

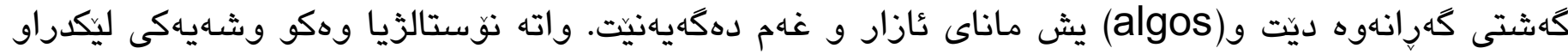

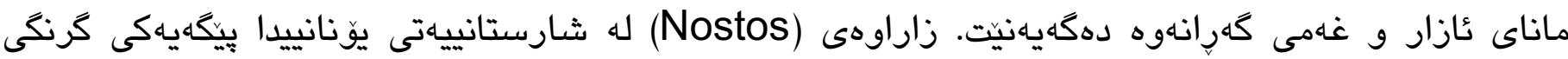

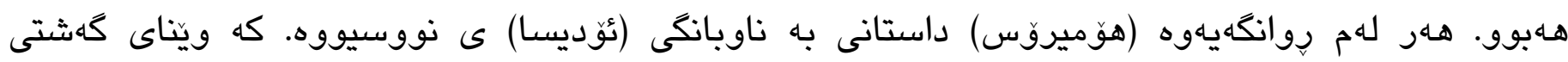

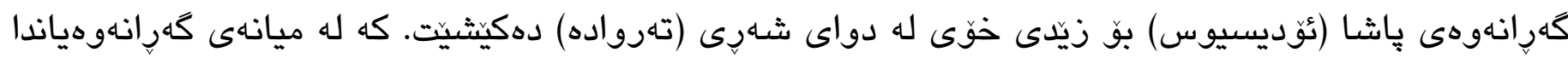
دووجارى ئازار و نارهحهتييهكى زور دهبنهوه، له رِووبهروو بوونهوهى بوونهوهره ئهفسانهييهكان و تووره بوونى خواوهند دا. (سالم، \1 •r، (https://manshoor.com/society/nostalgia-illness-and-meaning). ياخود دهكوتريت (نوستالزيا ئهو شـهوقهيه كه له ناخى كهسى تاراوكَنشينى دوور له زيّددا سهـرهـلْدهات و كوزارشت

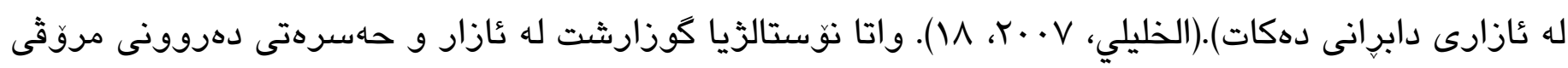
دوور له ولات و كهسوكار دهكات. نّستالزيا وابهستهى زهمهنى رِابردووه، بهو واتايهى كهسى نوستالزيى

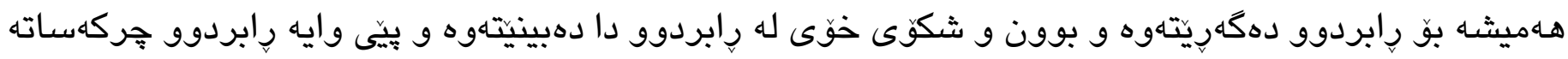
زيّرِينه له دهستجووهكانه و كئستهمه قهرهبوو بكريتاهوه، به مانايهكى ديكه (نوستالزيا بريتييه له

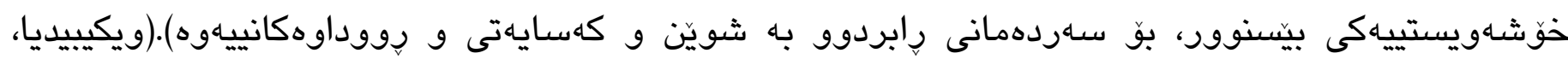
.(https://ar.wikipedia.org/wiki r.r. .

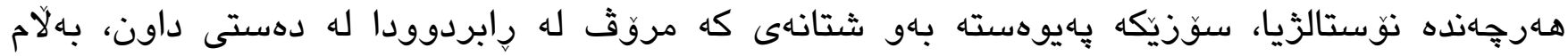
دهركهوتن و كاريكارييهكانى عُهم سوّزه له تاكيكهوه بوّ تاكيكى ديكه جياوازه، بهو مانايهى كه كاريكاريى زياتر له دنياى نووسـاراندا دروست دهكات و رهنكخانهوى له نيّو بهرهـهـكانيياندا هـيه (نوستالزيا سوزيّكى رِاستكوّيانهيه دهربارهى ثُهو شتانهى كه مروّق له دهستيداون، كه خوّى له شويَن و كهسوكار و كات و

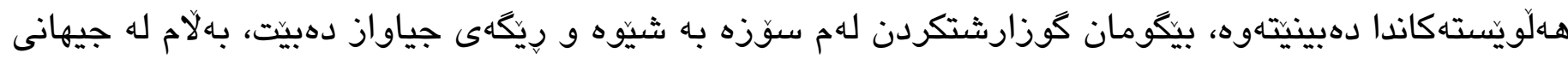

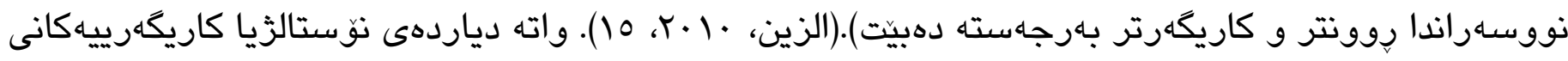

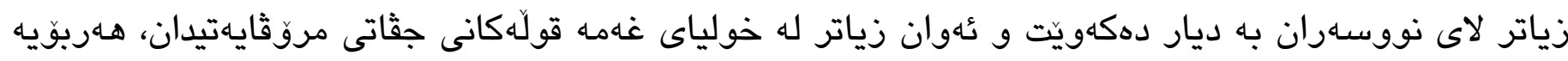

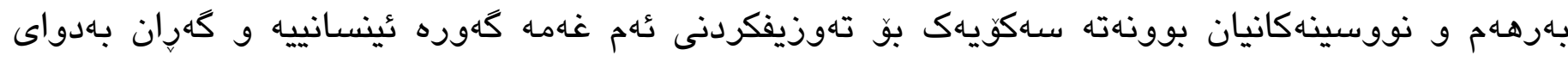

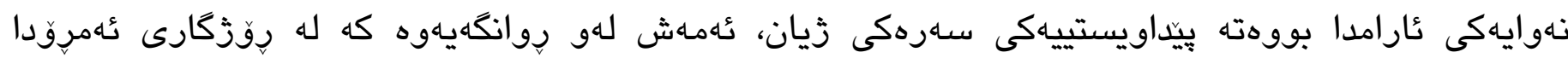

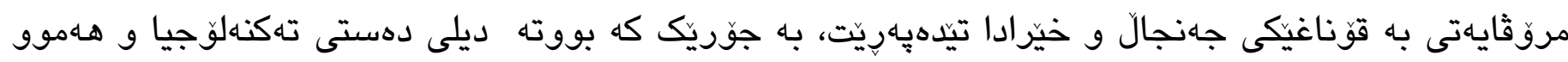

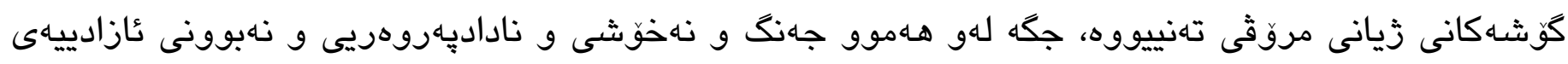
كه بهروكى بهشيكى كَورهى جيهانى كرتووه، كوقج و عاوارهيى و يهنابردنى مروّت بوّ زهمينهيهكى نارام بووهته 


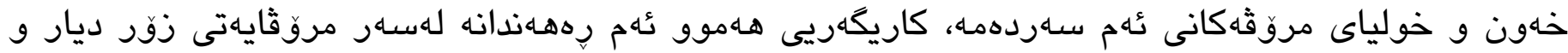

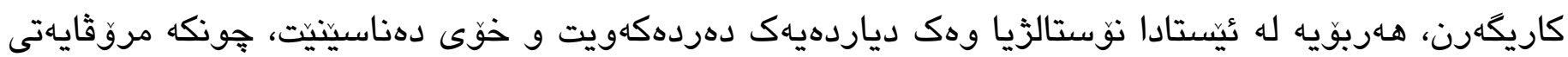

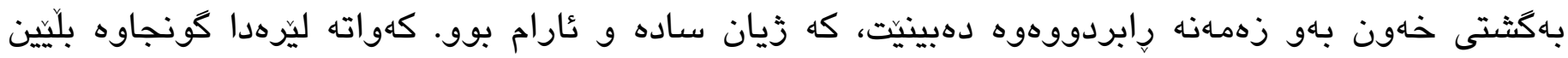
نوستالزيا زادهى دابرانه لهو شتانهى كه تاك له دهستى داون و بوونهته بهشيكى له رابردووى، بـ هـهوو يادهوهرييه تال و ثيرينهكانيهوه.

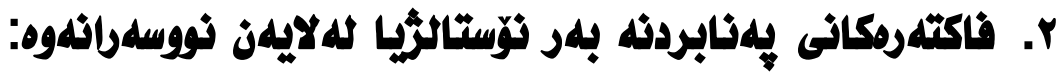

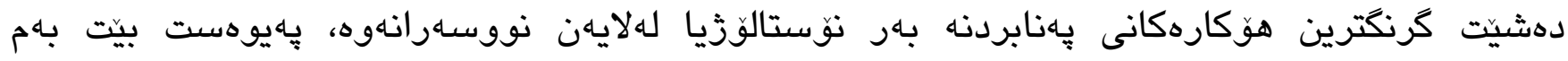

$$
\text { رههـهندانهى خوارهوه: }
$$

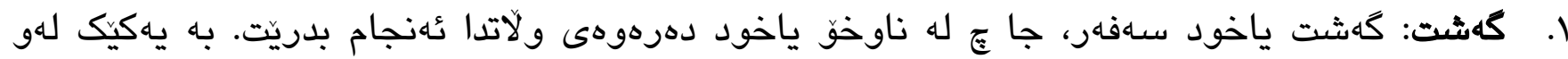

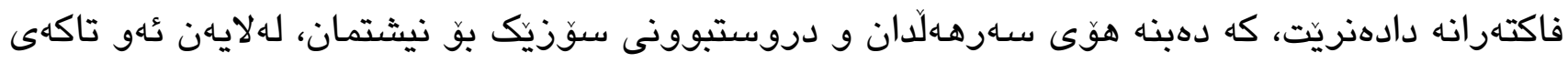

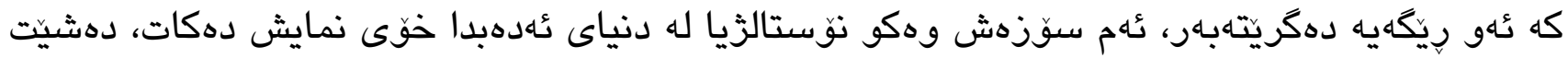

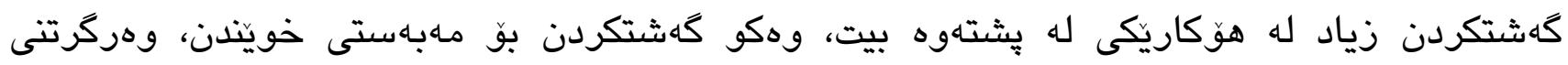
جارهسهرى نهخوشى، بو فهراهـم كردنى بزَيْوييهكى باشتر بو زيان ياخود وهكو حهز و خولياو

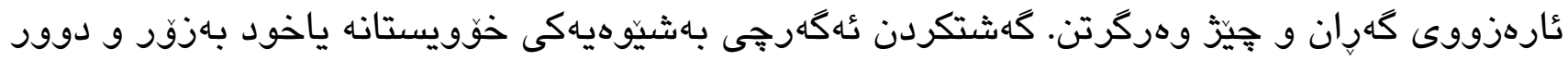

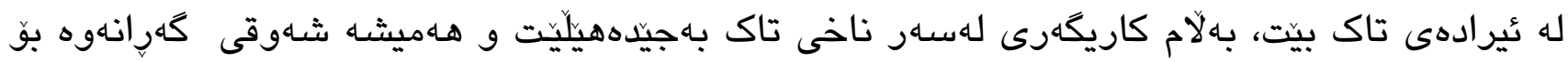

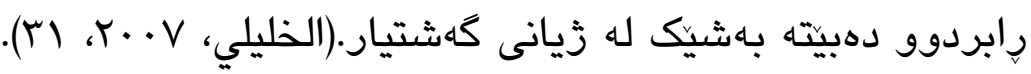
ץ. كرتن و دوورخستنهوه: هـلومـارجى رامياريى و نهبوونى عازاديى يهكيكى ديكهيه لهو هوكارانهى پيال

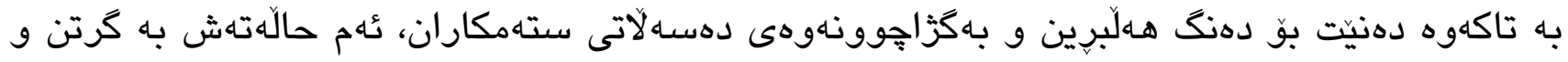
زيندانيكردن و دوورخستنهوهى ئازاديخوازان كوتايى ديت (تاكى زيندانيكرا و ياخود يهخسيركراو

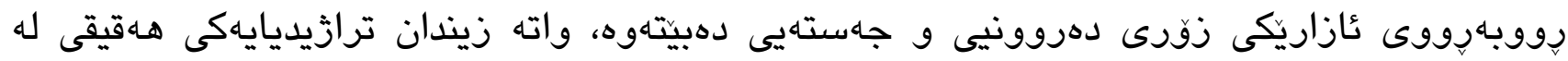
دهروونى كهـى زيندانيكراودا دهخولقينيتي، بهايبهتى لاىى تاكى نووسـه، كه تهنيا نووسين شك دهبات

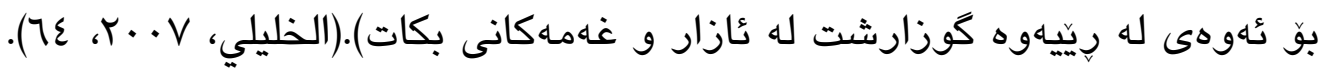

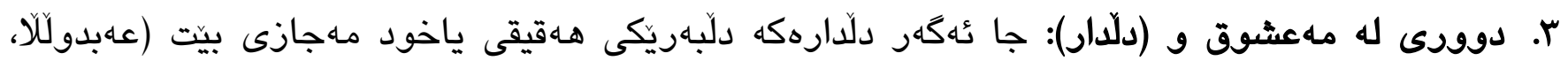

.$(77.17 \cdot 17$

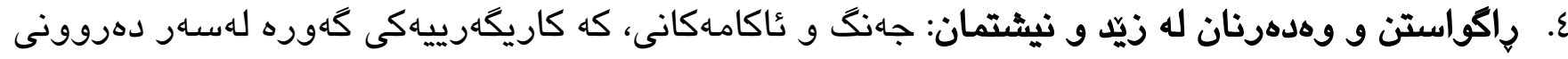

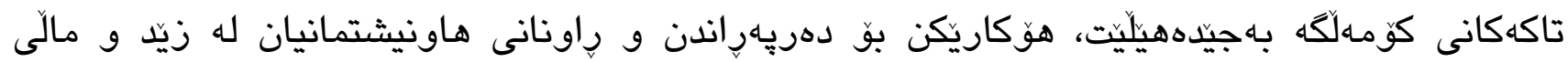

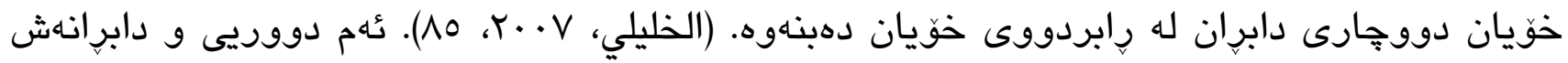

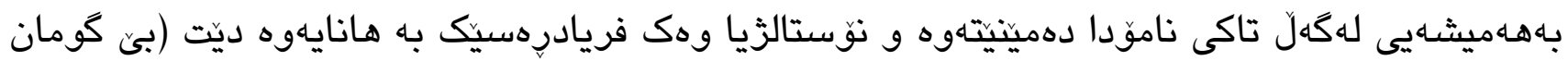

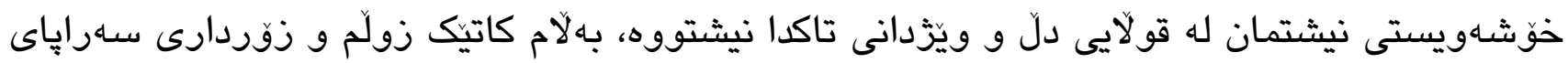




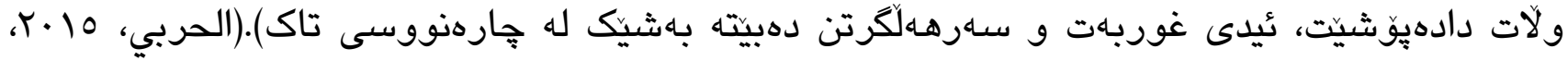

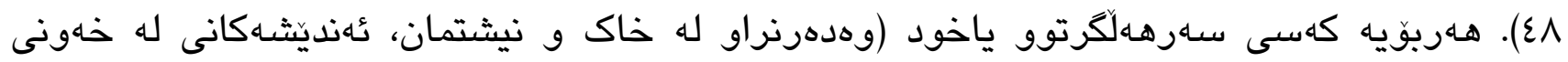

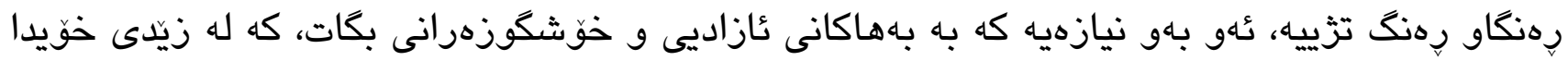

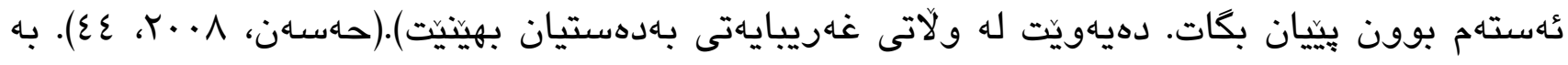

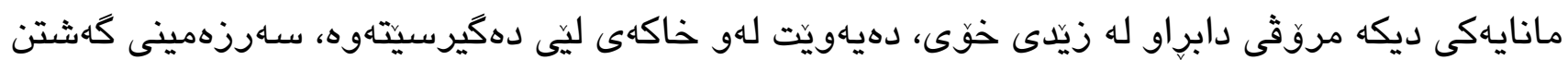
به خهونه بـانى بيت. ه. له دهستدانى ئازيزان: وهك له دهستدانى يهكيك له ئهندامانى خيزّان، يان خوّشهويستيك له زياندا، كه

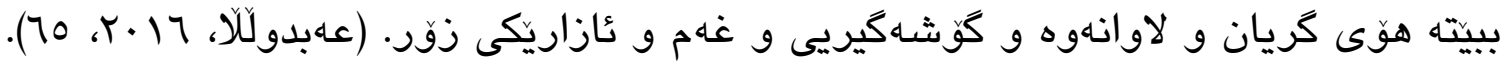

togog

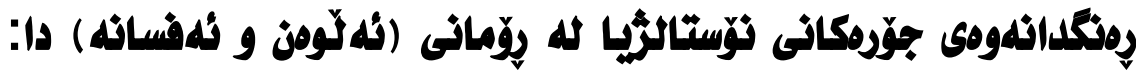

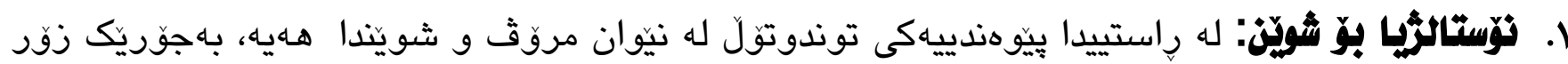

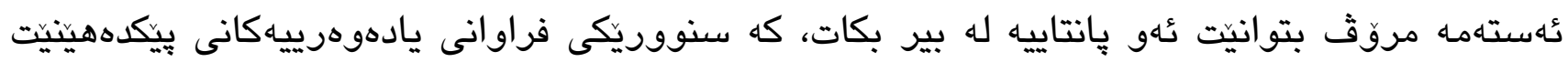

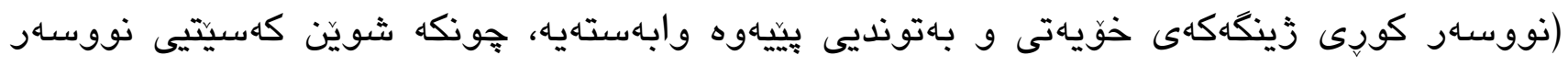
تهواو و كامل دهكات، هـهر له دهركهوتنيهوه تاكو بهكَشهكردنييدا رادهگات، هـربوّيه تُهو زينكَيهى كه

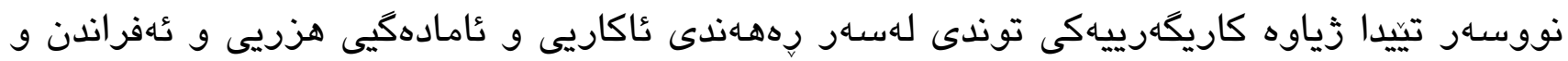

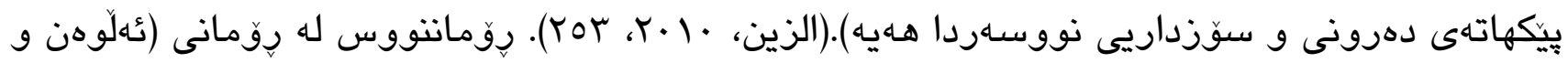

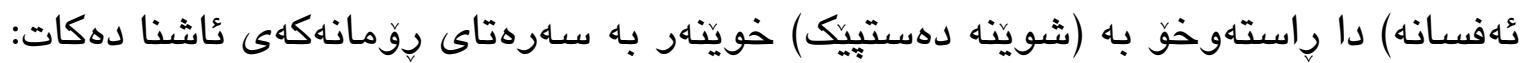

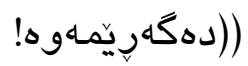

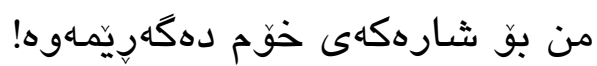

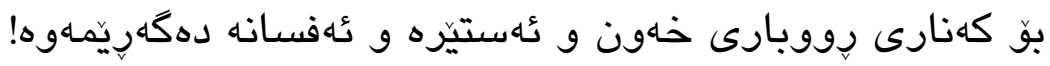

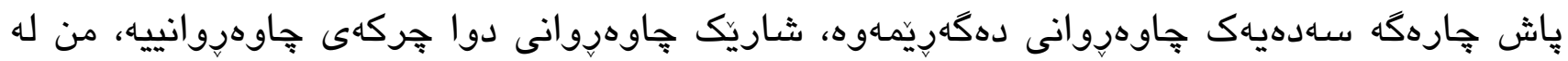
ئاميزيدا بزربم، يان ئهو له ئاميزّمدا بزر بيت. دايك و ساوا، ماوهيهك لهيهكتر دابران، ديسانهوه به

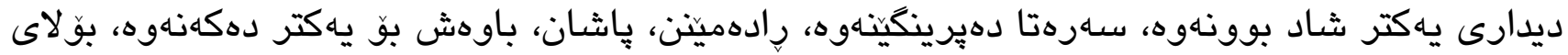

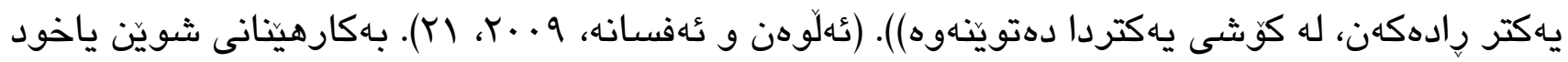

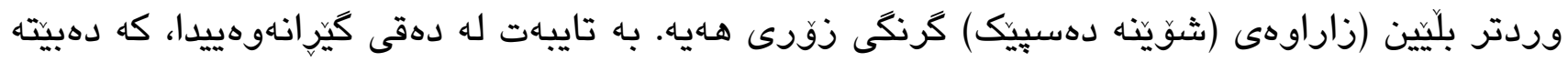

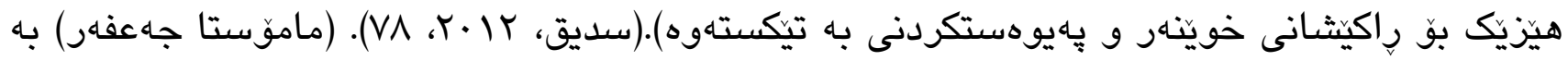
ثامازهدان به رِووباريك، بئ ئهوهى ناوى بهينيتِ و جوكرافياكهى ديارى بكات. وهركر له جاوهروانييدا

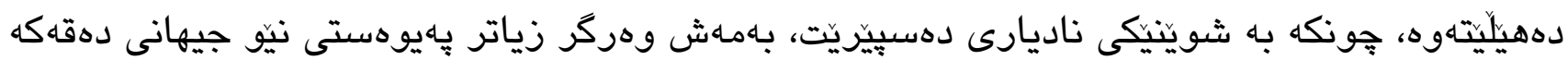




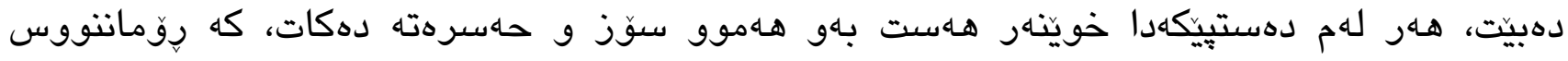

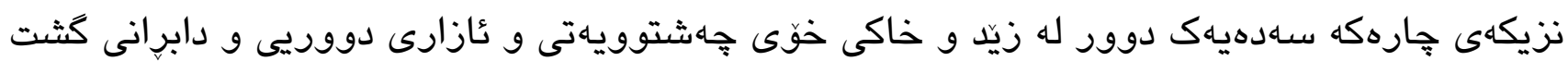
تئه ماوهيه ئوَقرهيان للهبهر بريووه.

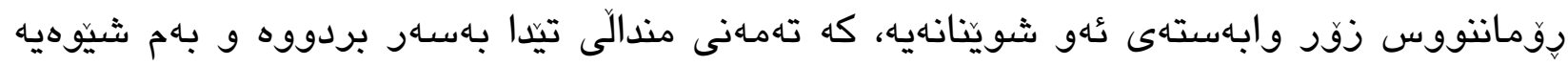
دهيانخاتهروو ((من لهسهر لمى كهنارى جوانترين دهرياشدابم، هـربيرم لاى ثئلوهن و سيروان و قؤرهتوو و هـواسـانه. بيرم نهماوه كهى فيّرى مـهلهوانى بووم. يهكهمين جار له تهقتهق و بـهر پِاشان له

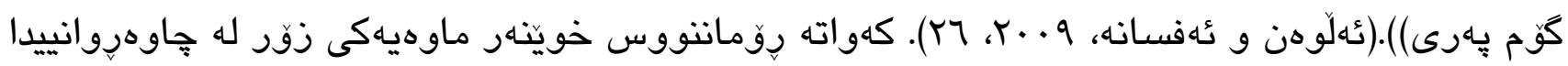

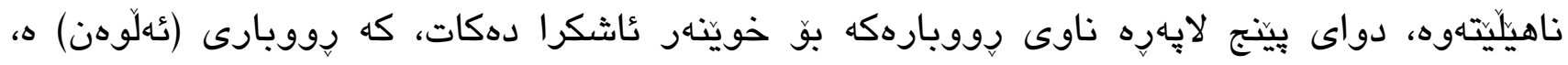

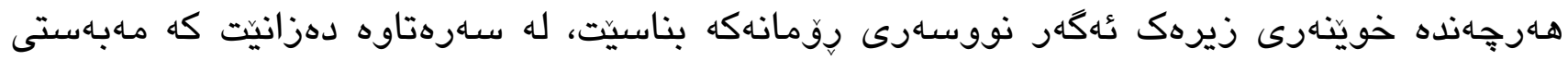

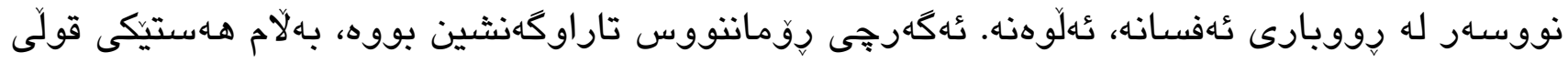

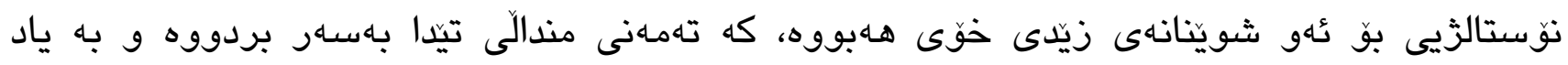

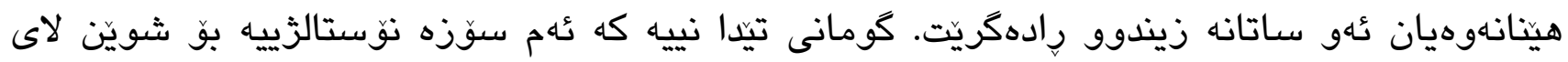

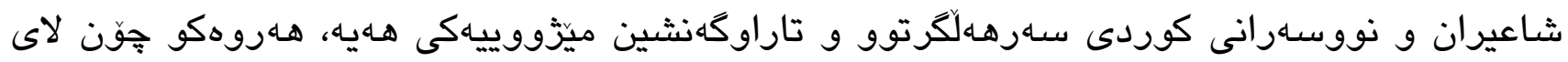

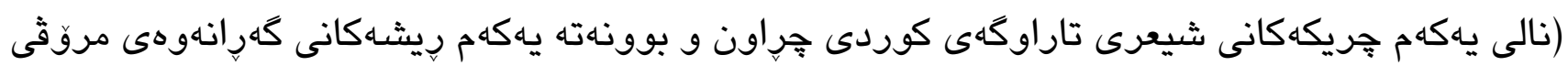

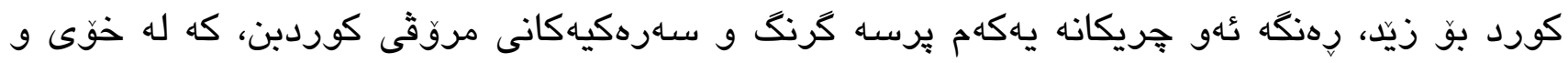

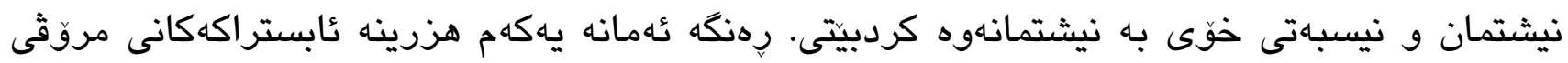

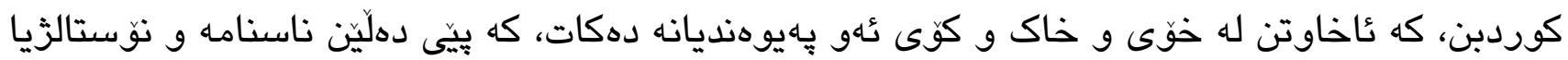

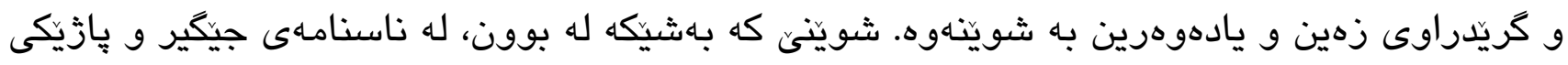

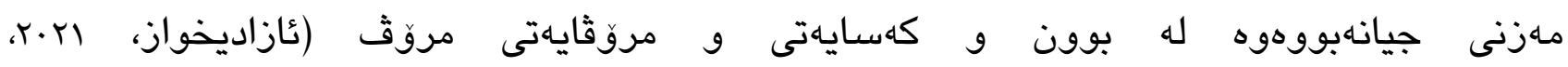

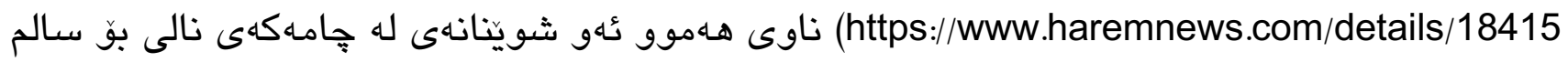

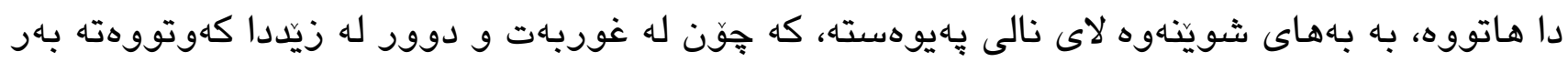

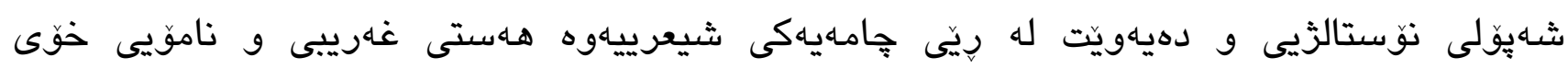
دابمركينيتتهوه.

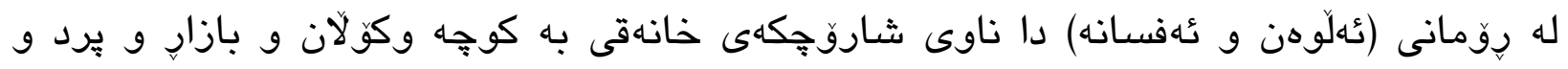

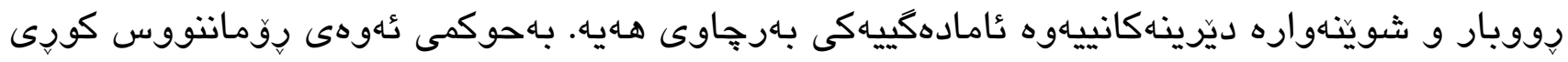
ئهو شـارهيه و تهمهنيكى لهو شـارهدا كُزهراندووه، هـر ئهمهاش وايكردووه كه رهنكدانهوهى رِاستهوخوىى

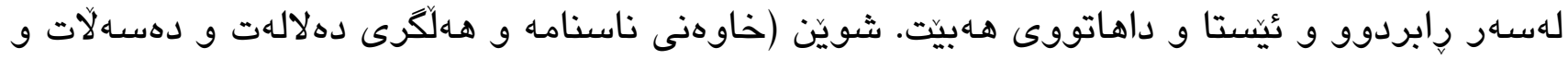

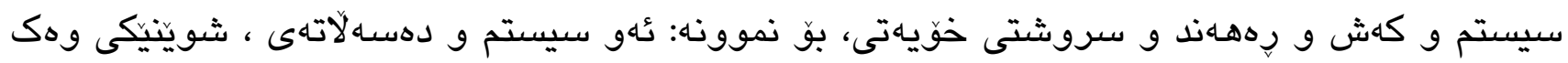

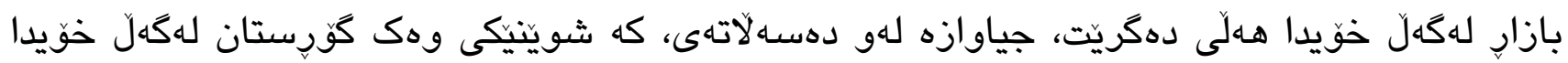

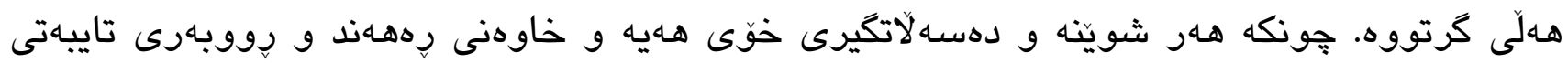




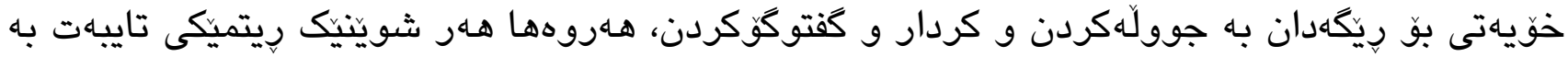

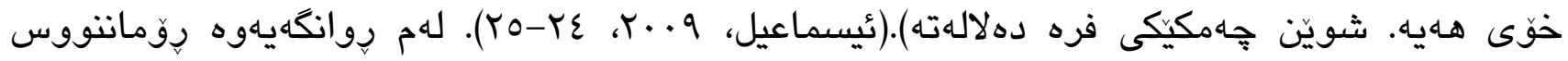

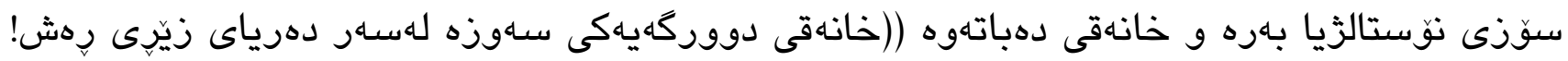

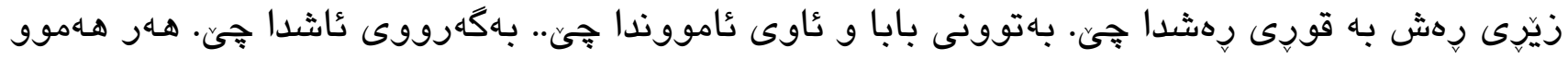

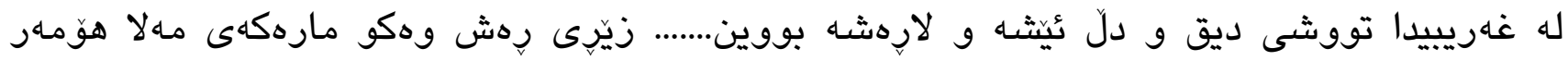

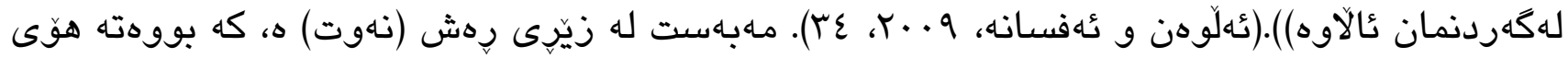
ئهو دابرانه و خانهقينيشى كردووه به جوكرافيايهكى سياسى، ئهينا دوزمن هيج ئيشيكى بهو رووبهاه

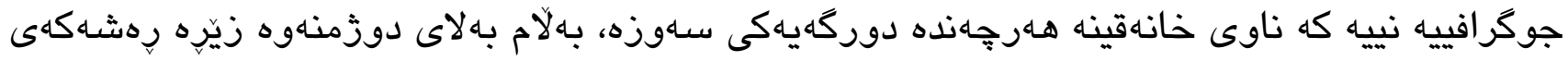

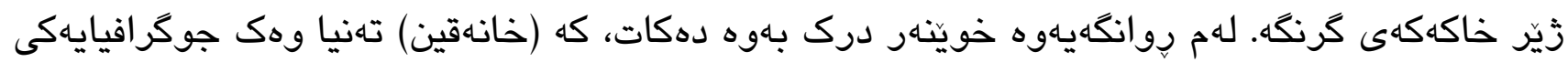
سنووردار مامهلّهى لهتهكدا نهكراوه، بهلكّو خاوهنى مهدلووليكى فراوانتره و به كيثشهى نهتهوهى كوردهوه يهيوهسته، بوّيه دهثيّت بكَوتريّت كه شارى خانهقى له رِومانهكهدا له عاستى سمبولدا مامـلّهى لهتهكا كراوه و دهربرينى سوّز بوّ دهثهرى خانهقين سوّزه بوّ نيشتمان. به واتايهكى ديكه (زهوى

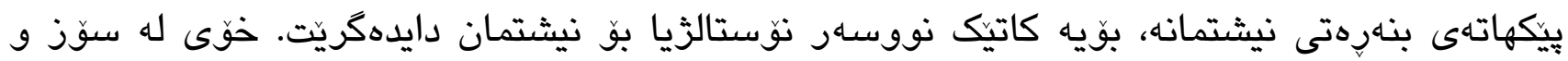
حهسرهت بو زهويى و هـموو رههـنده سروشتيهكانييدا دهبينيتهوه، كه بريتين له جيا، رووبار، ئاسمان، دارودرهخت و دهثتهكان، جگَه لهو شويَنانهى كه مروّق هـهر له مندالَيهوه هوَرىى بووه و دنيايهك

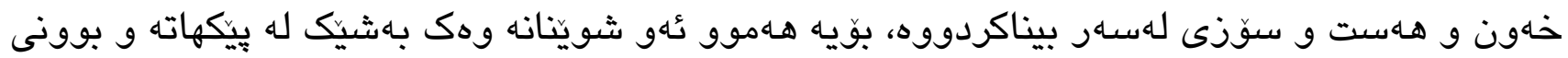
تاك سـير دهكريّ، كه دابِان و دووكهوتنهوه لهو شوينانه لاى هـنديَك له نووسـاران جوريكه له

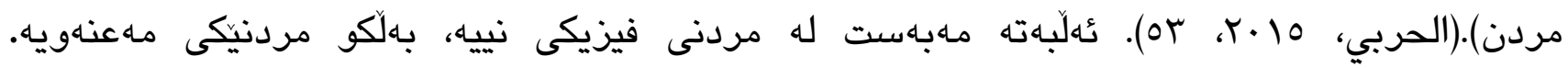

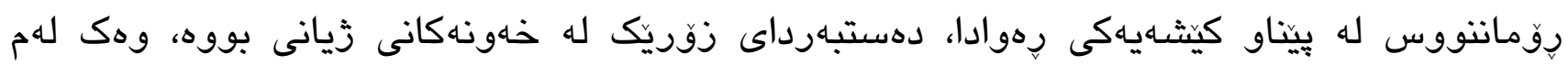
دايهلوَكهدا دهردهكهويّت: رِومانتووس((كاتيك به كاك بهختيارم كوت:

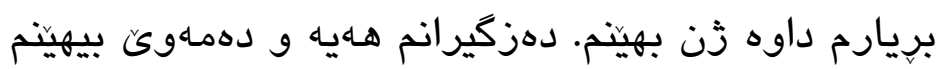
كاك بهختيار كوتى:

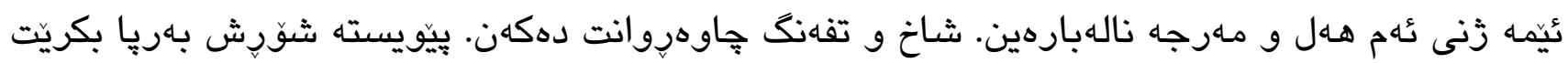

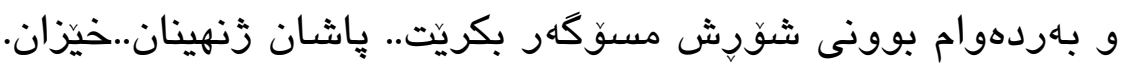
ماموّستا موحسن يِيَى كوتم: تق و صادق دهبئ زوو روو بكهنه شاخ. زمارهيهك كادرى سياسى و عهسكهرى شههيد كراون، دهبيّ

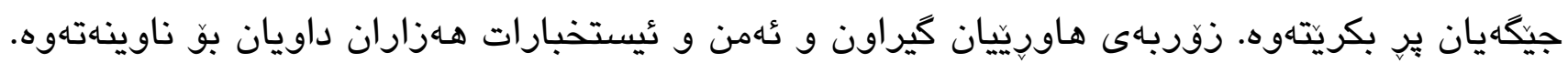

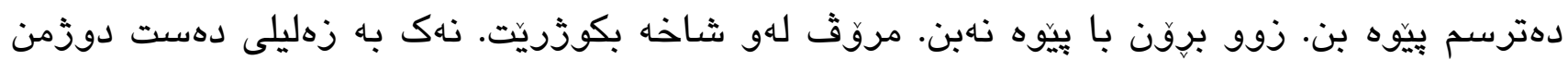

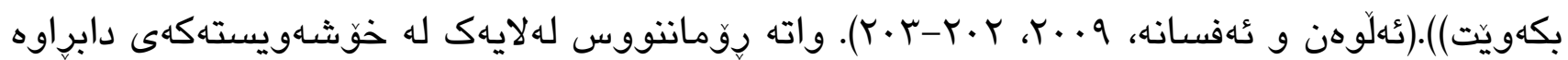


لهلايهكى ترهوه له كوجه و كوَلان و لانهى يادهوهرييهكانى و ناجِار بووه ريَّاهى شاخ بحريتهبهر، ئيدى

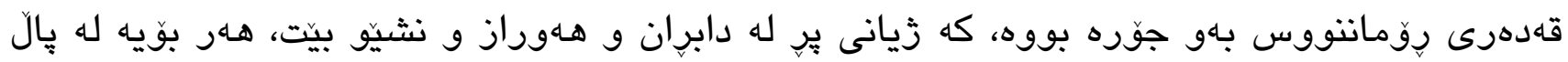

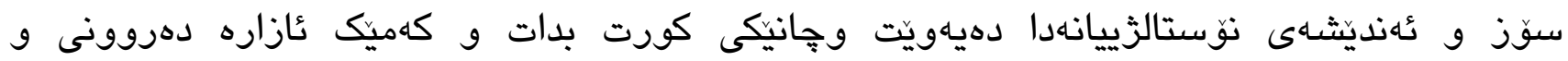
جهاهتهيياكانى وهلانيت.

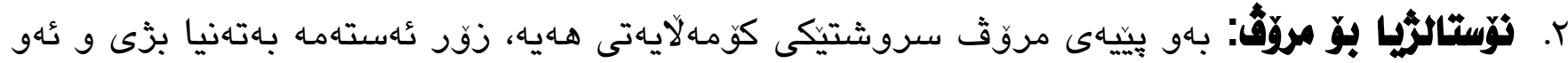
كهسانه له ياد بكات، كه بهركهوتنى بـردهوامى له كُلّياندا هـبووه، جا تج وهك دايك و باوك و كهسانى نيّو خانهوادهكهى ياخود خوَثـهويست و هاوريِيانى تهمهنى، هـربوّيه له دوورى و عاوارهييدا زياتر هزرى

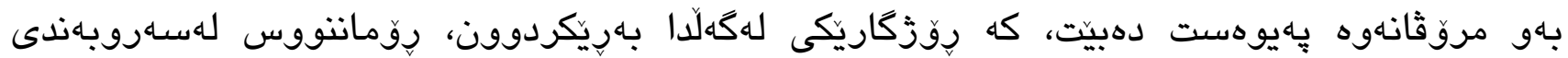

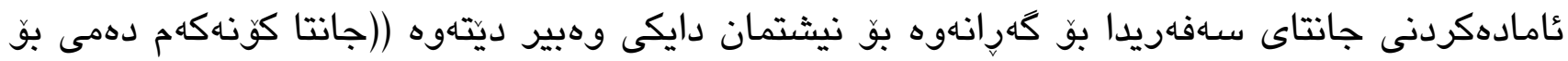

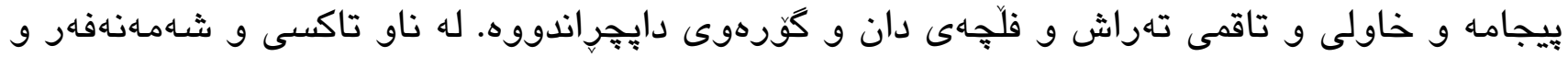

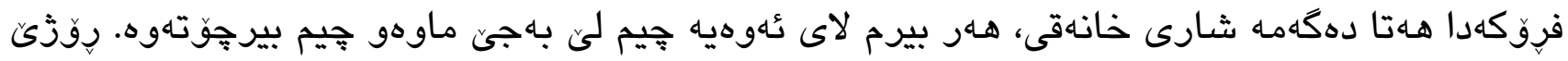

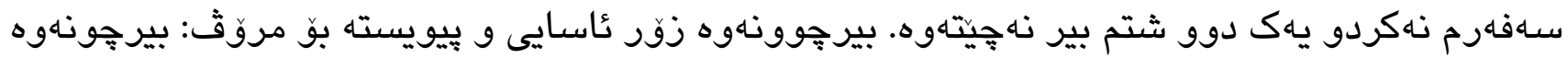

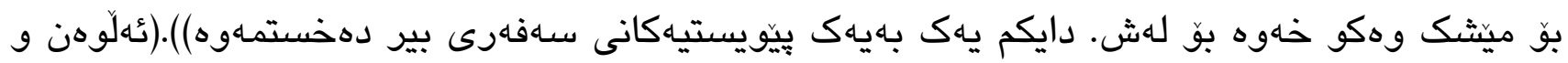

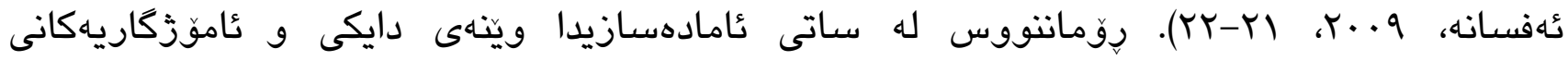

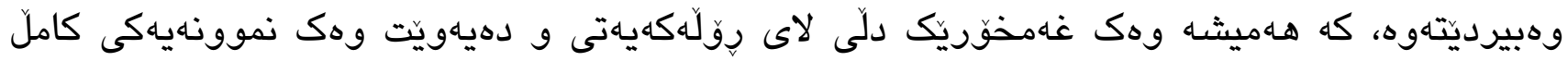

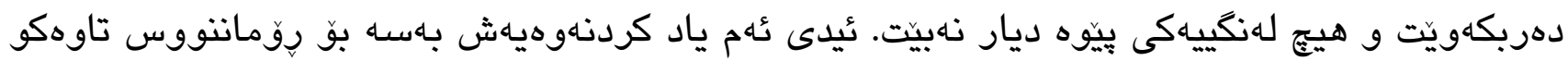

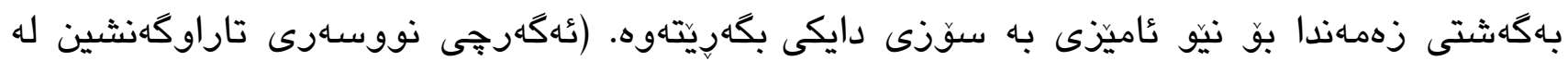
زيّدى خَوى دووركهوتووهتهوه و له جيهانيكى نويّدا كيرساوهتهوه، بوّيه سوزىى تهنيا وابهستهى عُهو

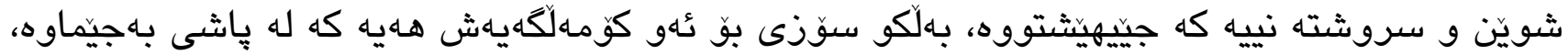

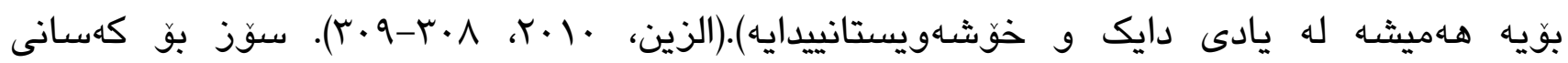

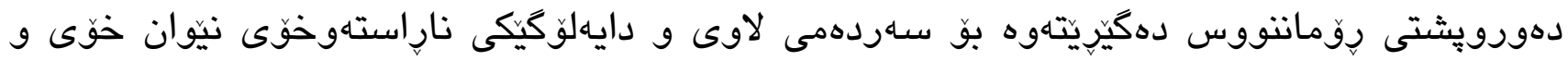

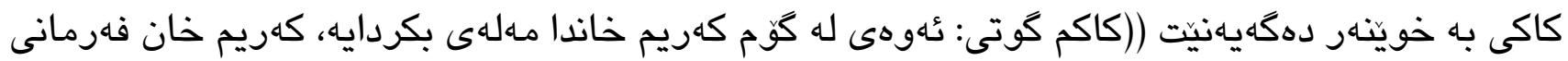
دهدا له تاوهدا روّنى بوّ داخ بكهن و بهقوركيدا بكهن. به كاكم كوت: ئهوه نييه ئيمهـ له كُّم كهريم خاندا مـله ئهكهين و كهس هـهى بهسهارمانهوه نييه! ئهو كَتى: كهريم خان مردووه. زهمانى ئهوهش نهاهاوه

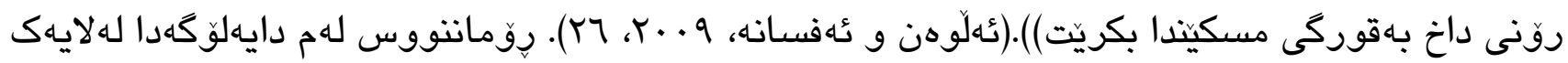
به كاكى شاد دهينتهوه و حهسرهتى دووريى و دابِّانى له ياد دهكات، لهلايهكى ديكهوه ثامازه به ئاستى هوّثياريى و كامل بوونى هزرى خوّى و كاكى دهكات لهسهردهمى لاويتيّدا، كه دزى هينايهتى بوون.

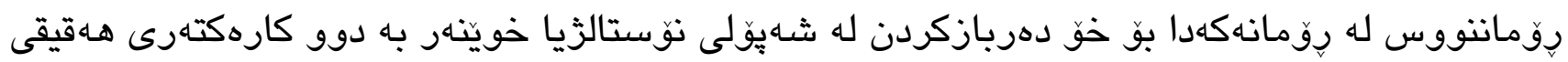

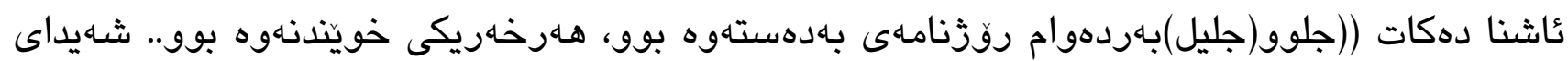
دهنگ و باسى جيهان بوو.. سهمينهش زوّر حهزى له رِوزنامه خويِندنهوه بوو: 


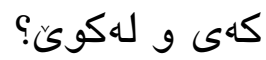

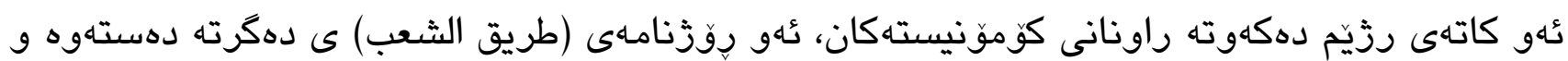

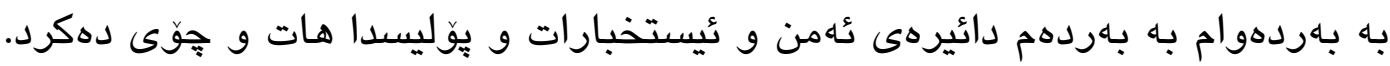

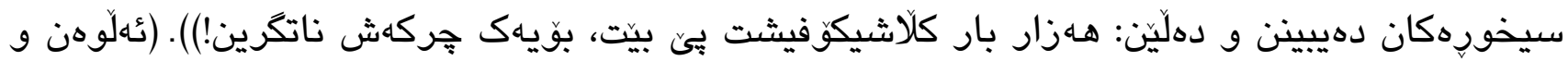

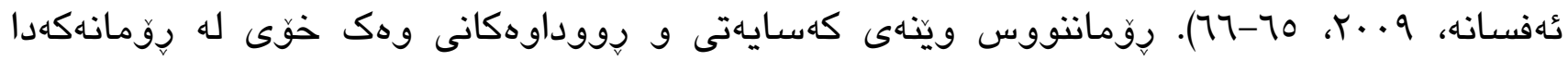

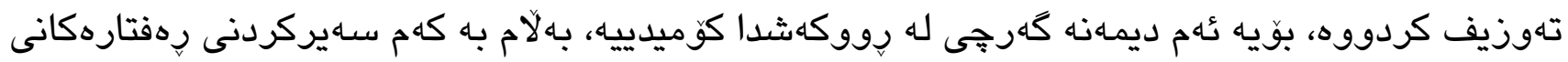

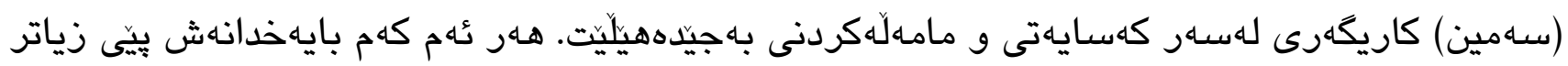

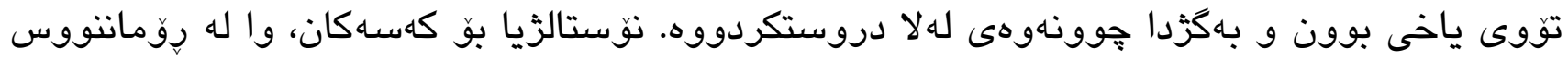

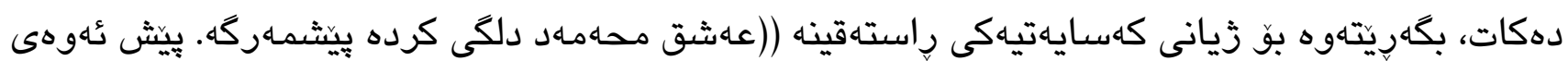

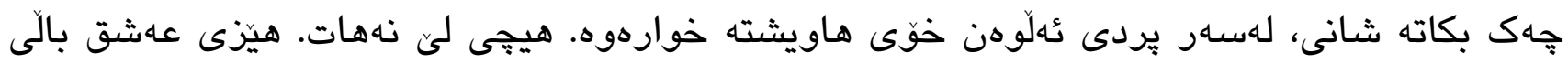

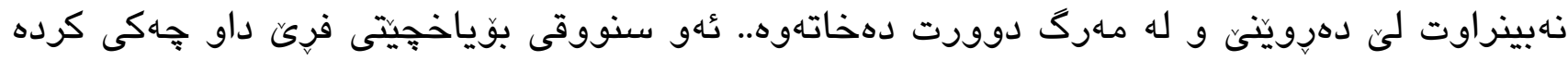

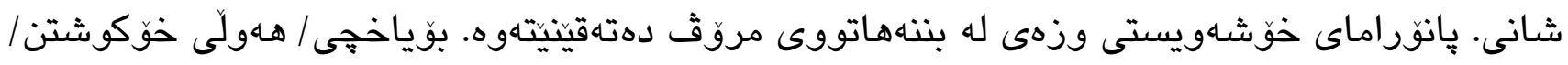

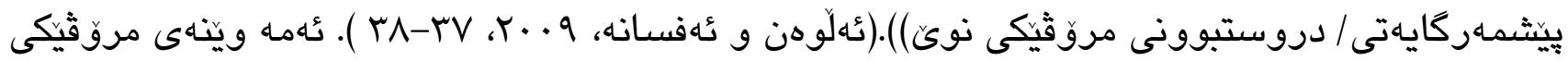

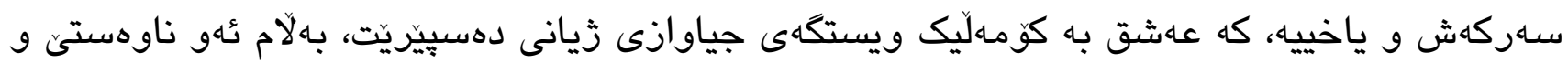

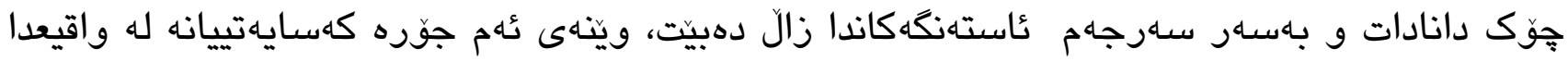

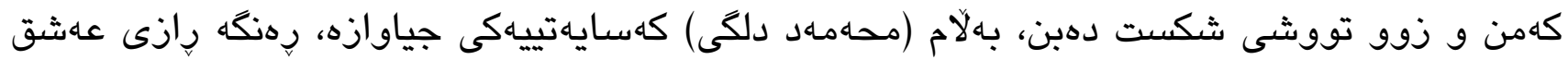

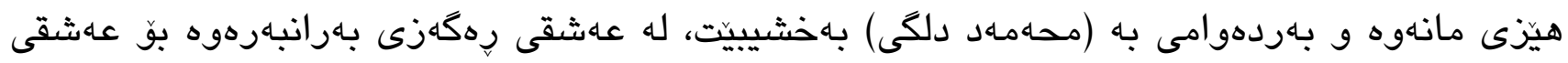
خاك و نيشتمان. روماننووس دوو كهايهتى ديكه به وهركر دهناسينيت، له كَشته نوستالزييهكهيدا

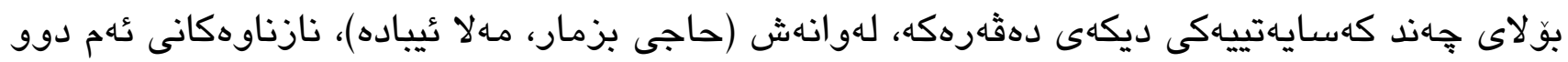
كهايهتييه تهواوكهرى بيشه و هـلَّوكهوت و مامهلّيان بووه لهكهل بهرانبهردا، (حاجى بزمار) نازناوهكهى لهويّوه بينى برابوو، كه ((بزمارى دهفروشت و قسهكانيثى وهكو بزمار بوون تاقهتى ساواو

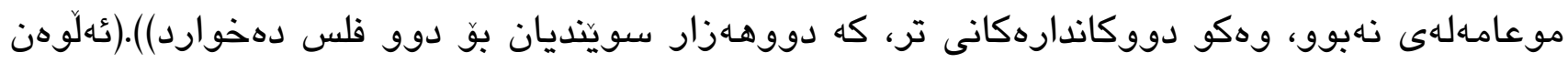

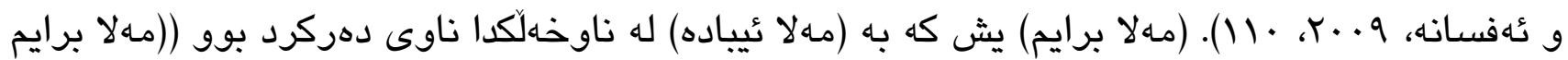

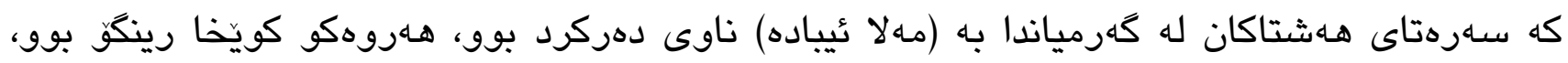

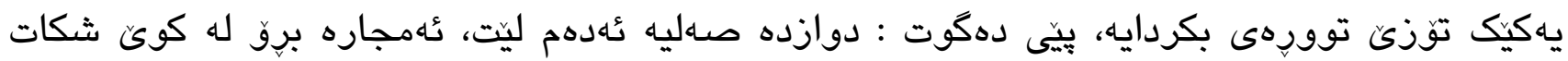

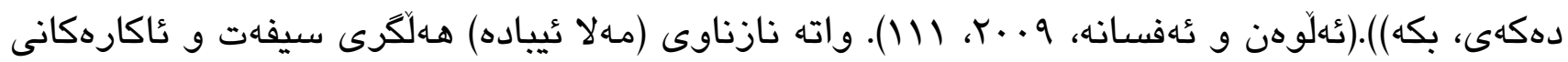

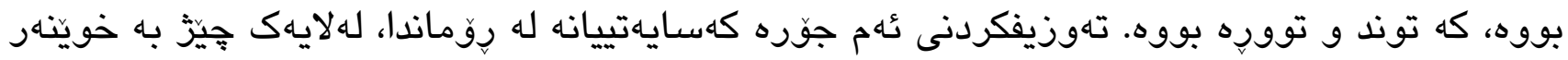

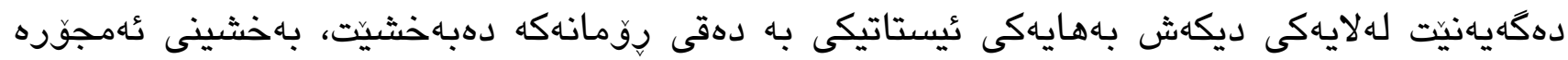

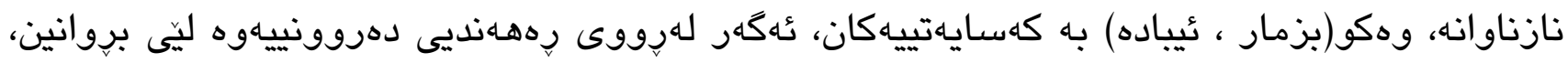




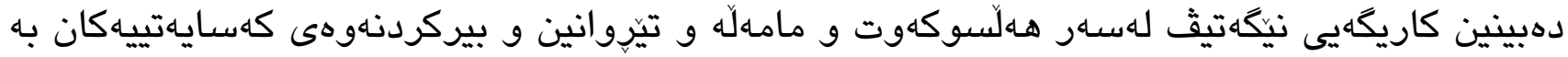

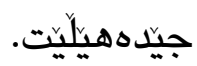

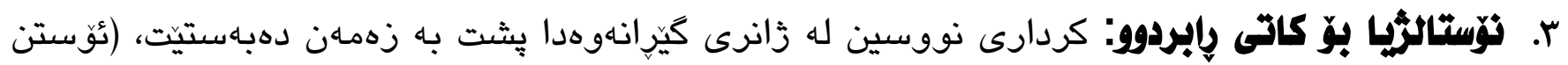

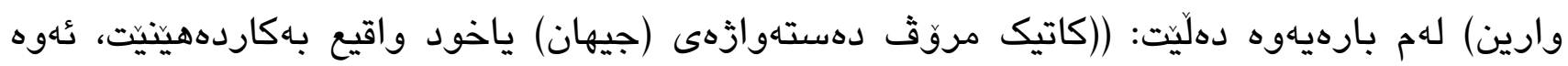

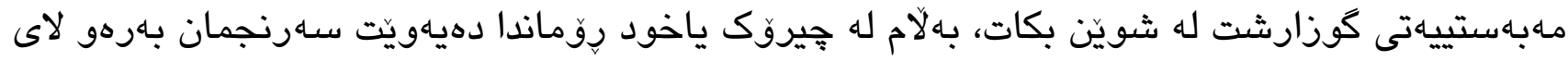

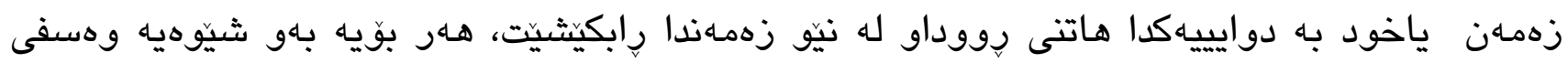

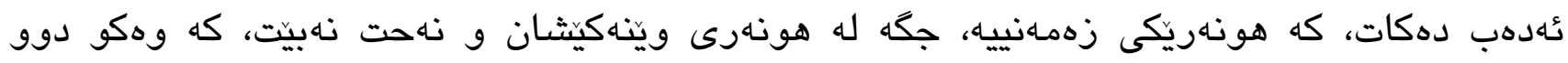

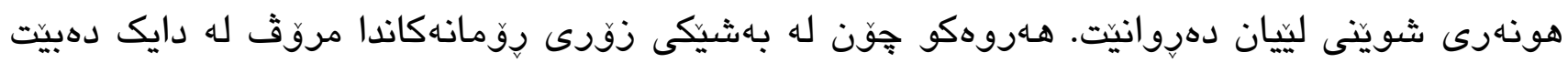

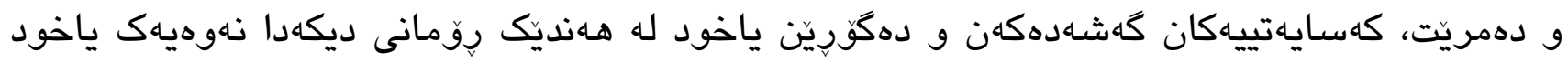

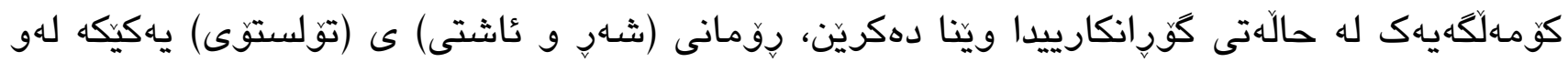

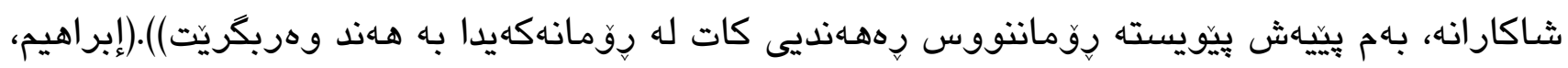

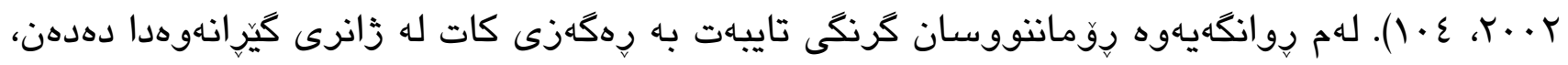

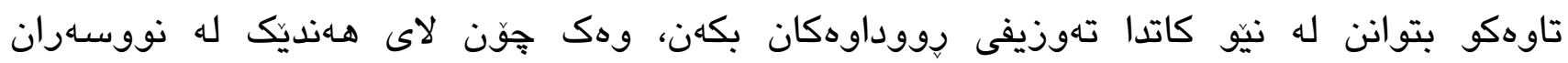

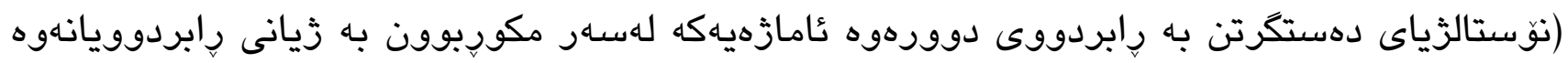

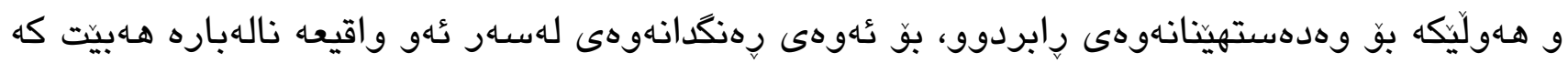

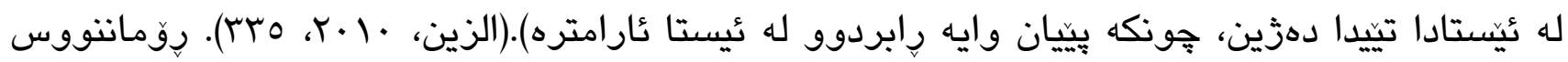

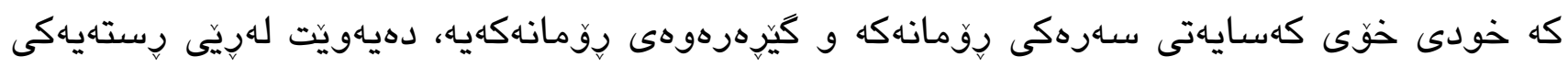

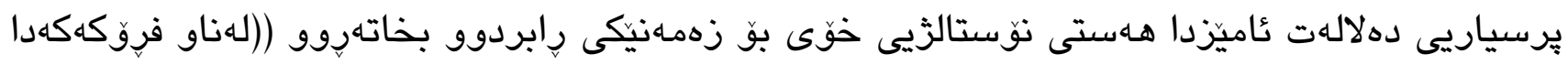

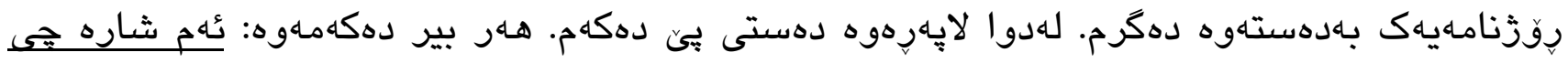

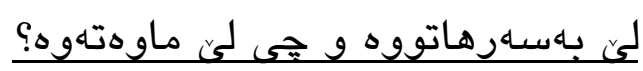

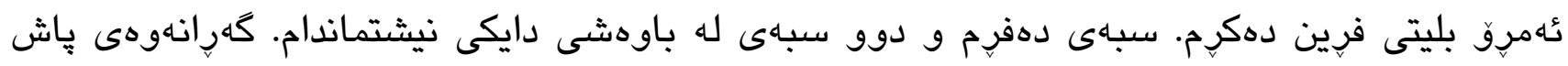

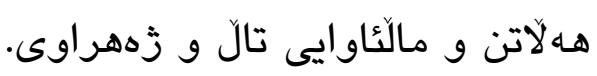

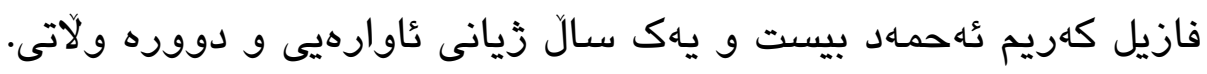

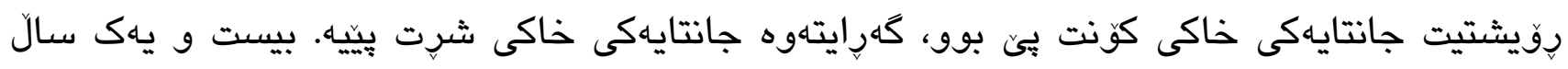

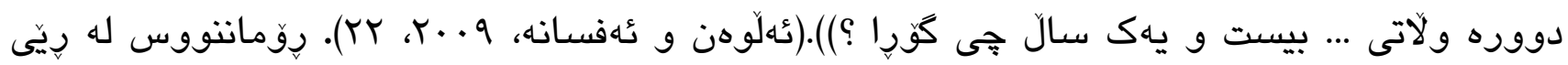

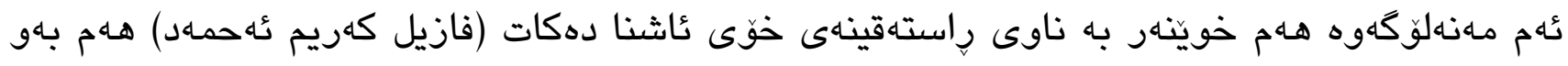

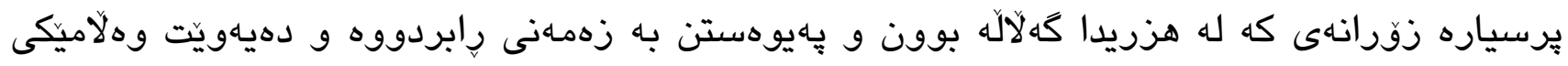

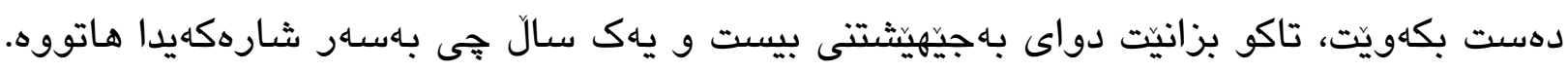

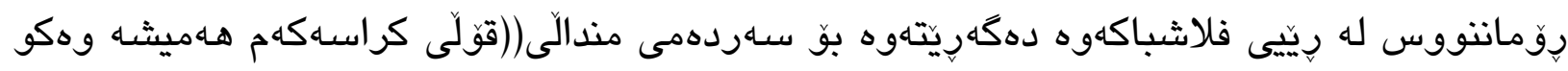

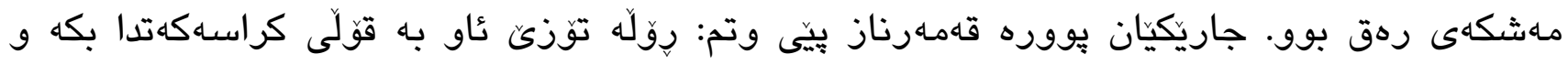


دهستيكى يِيا بينته. جينينكى جهلاتيى سهوز لهسهار مهشكه رهقهكه دروست بيوو، هـرجيم دهكرد ليّى

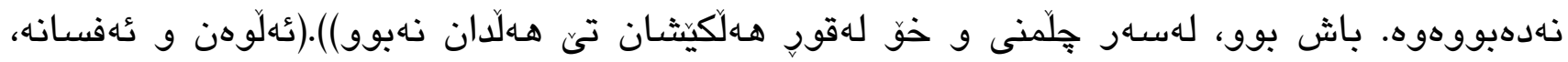

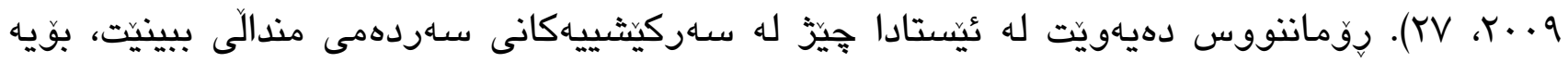

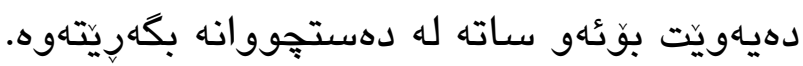
دياردهى نوستالزيا له غهريبى جياوازه له نوستالزيا له نيّو خاك و نيشتمان، جونكه بهينيى ياساى

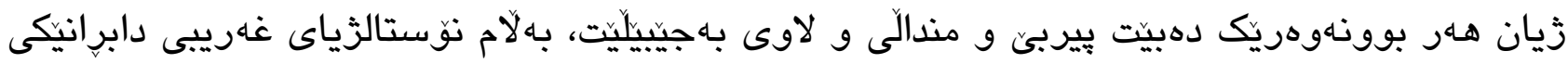
فيزيكى و رهوانييه، نووسـار له ناكاو خوّى له شوينتيك دهبينيتهوه كه هيج نيشانهيهكى له رابردوو بيّوه

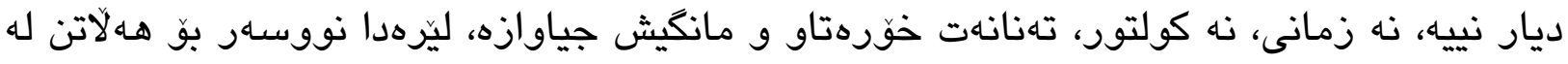

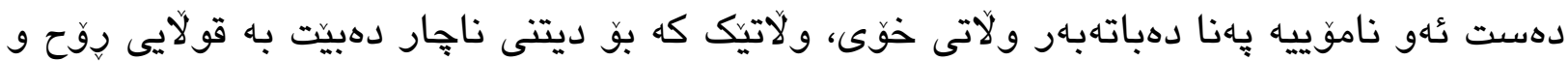

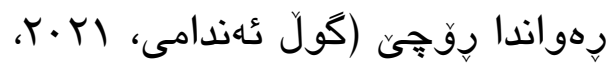
(http://hemin.dk/DAQIKURDI/2009/TA_chirokWnwstalwzhiya_SGA.htm حهسرهت و عاخهوه رِومانتووس دهكَرِيتهوه بو رابردوويهكى دوور و وهسفى شهويكى خانهقين له يادى عاشوورا دا دهكات ((شهوانى عاشوورا، دلّى شار مواكيبى حوسيّينيه بوو. رهوزه خويندن و درووشمهكان بهره بهره له عهرهبى و فارسيهوه دهبوونه كوردى، ئهمه ترسى دهخسته دلّى

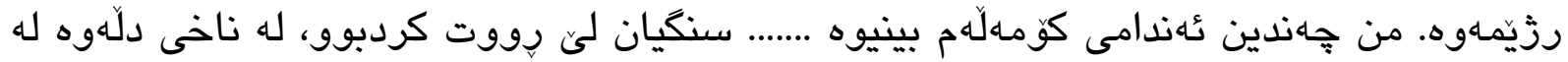

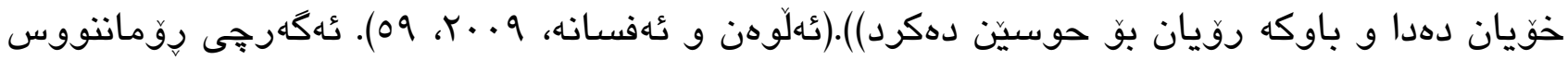

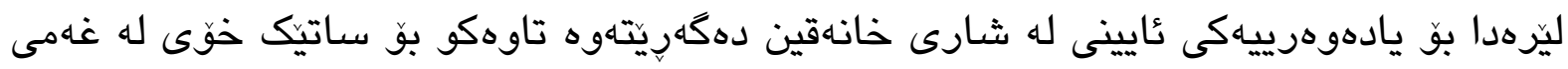

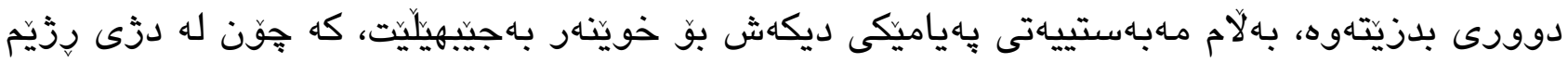

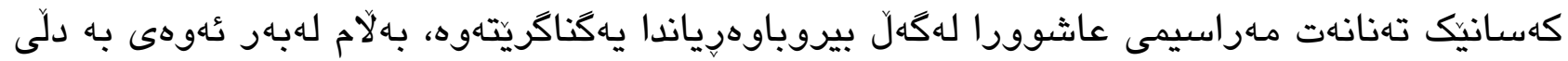

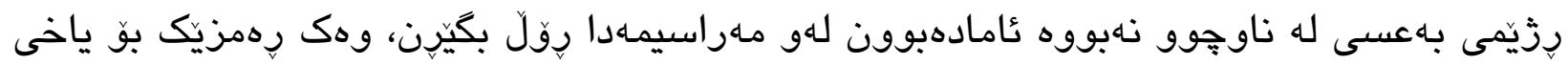

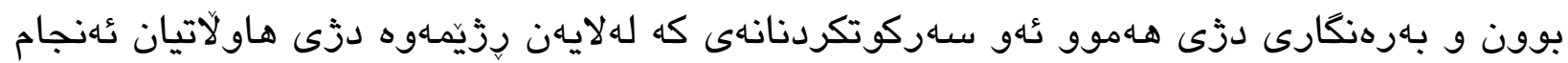
دهدرا.

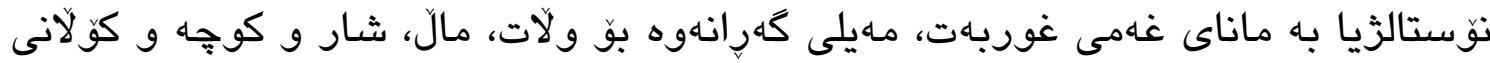
مندالييه، دونياى نوسين زور بهر بلاوه، ساتيك يادى جاران هـست و بيرى نووسـهر دهوروزينحى و

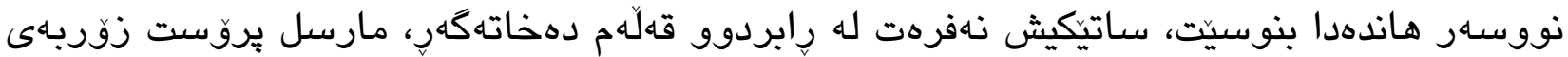

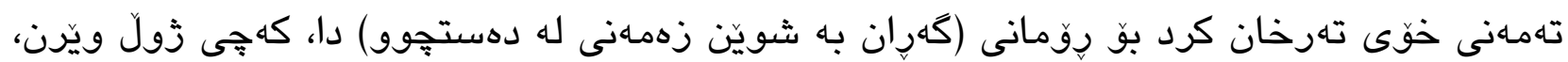

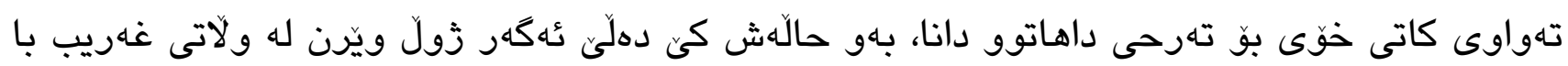

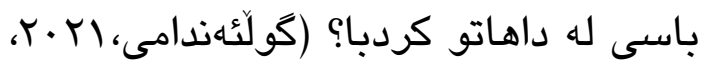
.(http://hemin.dk/DAQIKURDI/2009/TA_chirokWnwstalwzhiya_SGA.htm) 
لوتكهى نوستالزيا كُهرانهوهيه بّ سـاتى مندالّى، ياد كردنهوهى ئهو ساتانهيه كه تاك خاوهنى دنيايهى

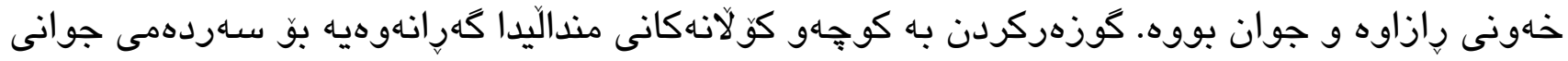

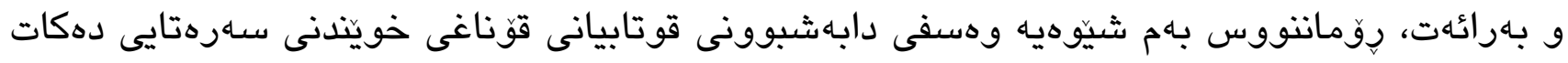

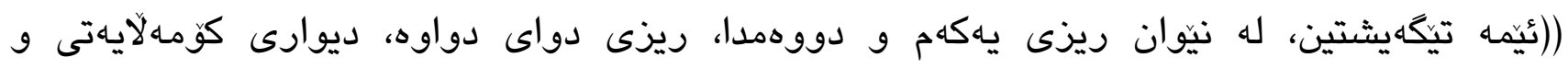

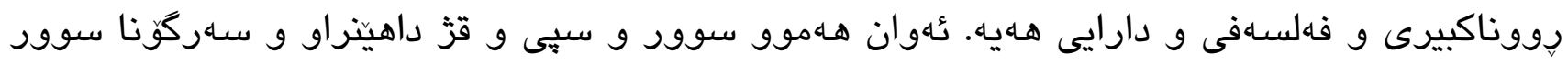

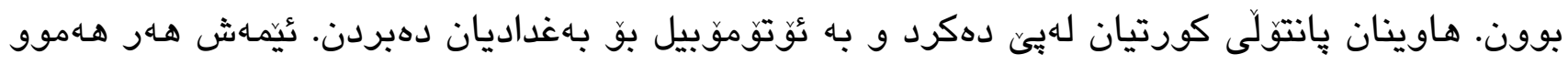

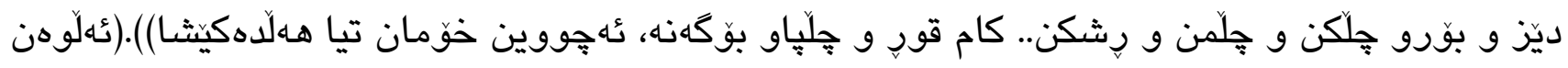

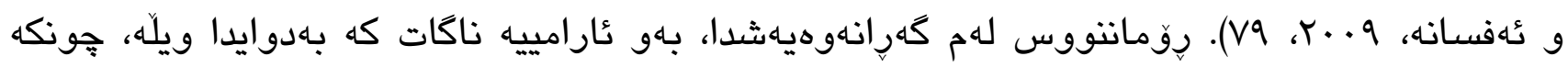
دابهشبوونى قوتابيهكان له ريزهكاندا، ئامازهيهك بووه بو جياوازى ثاستى كومهلاّيهتى و ثابووريى و

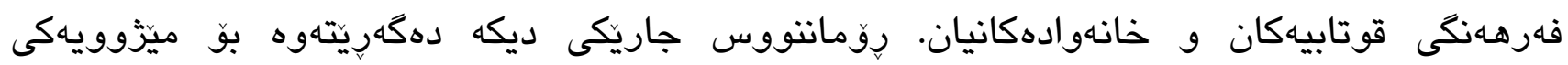

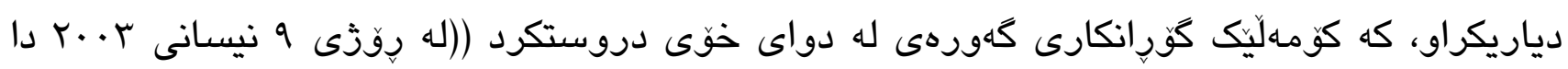

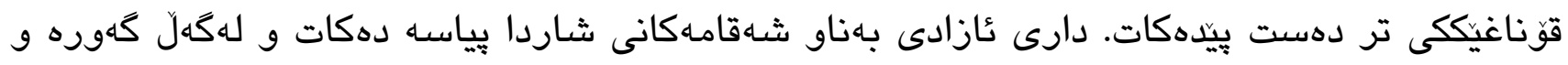

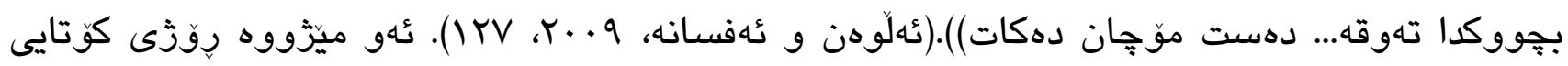

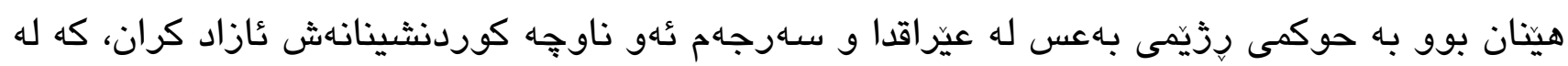

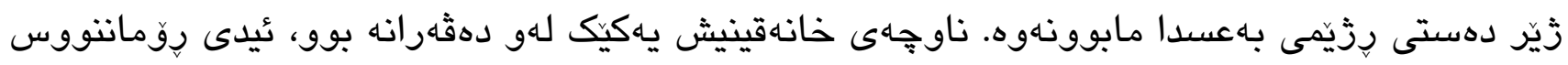

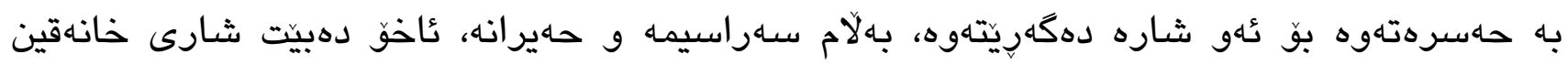
هـامان ئهفسوون و تام و بوّنى جارانى مابيتِ؟ عُهمه عُهو سـاتهيه كه رِوماننووس دواى دابرِانى نزيكه

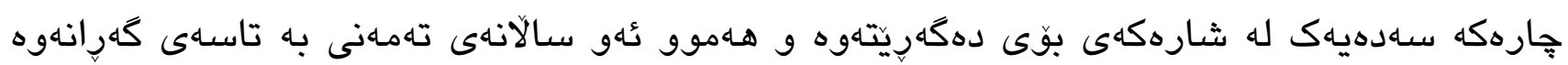
بووه بوّ ديدارى خاك و نيشتمان، بهلاّم رِوماننووس هـهت به نيگُرانييهكى كهوره دهكات ((من دهترسم، هـر زقوريش دهترسم، هـه زقر زقريش دهترسم! نهمن شـهامهان بناسماهوو نهشهامامـكان من

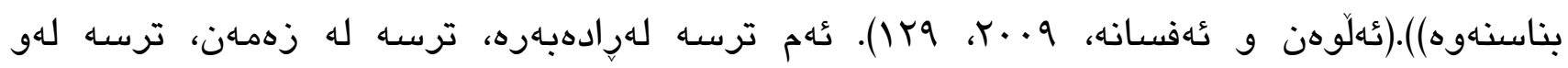

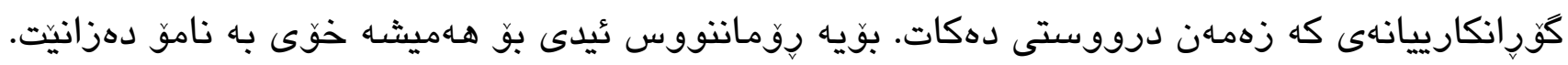
جونكه نه له تاراوكه هـهت به ئارامى دهكات، نه له باوهشى نيثتماندا، ئيدى تئهـ قهدهرى مروّثه،

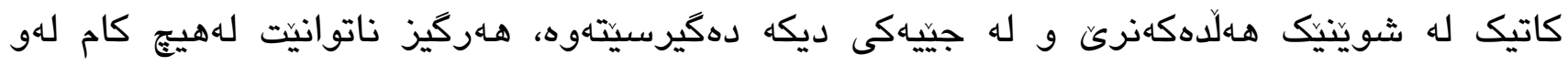

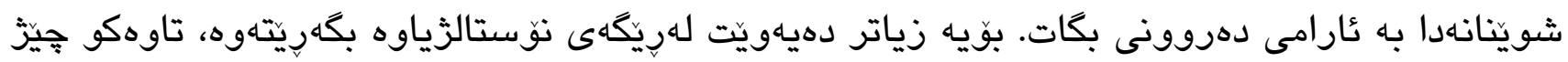
له ساته له دهستجووهكانى وهريكريّت. 


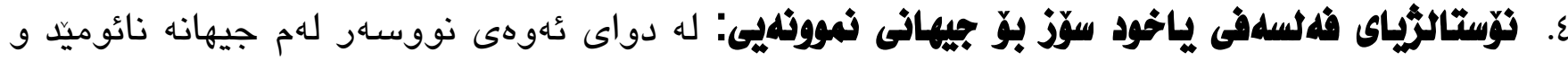

دلّثكاو دهبيت، دهكاته ئهو باوهرهى ئيدى جوكرافيايهك ياخود سنووريّك نهماوه بو ئهوهى ئهو تييدا

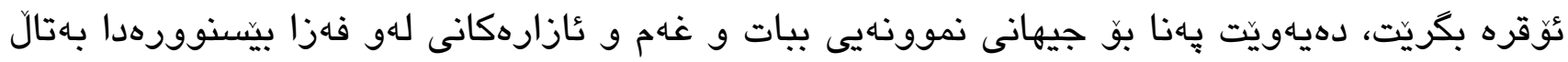
بكاتهوه، ئهو جيهانهش كه نووسهار دهيخوازيّت خوّى تيدا بيينيتهوه دنياى نووسينه، هلهر بوّيه ئهم جوّره به نوستالزياى فهلسهفى ياخود سوّز و حهسرهت بو جيهانيكى نموونهيى ناو دهبريّت (نووسينى ئهدهبى و فهلسهافى دوو وينّن بو كوزارشتكردن له بوونى تاك، به واتايهى ديكه بِروّسهى نووسين نزيكترين

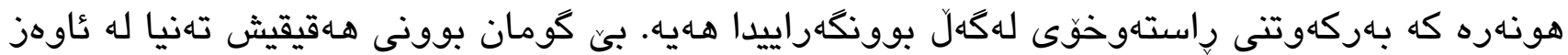

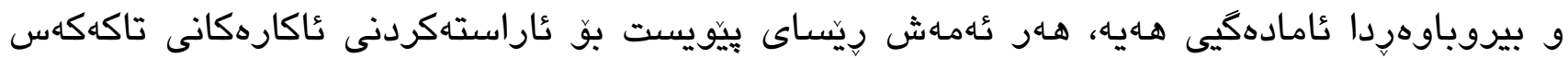

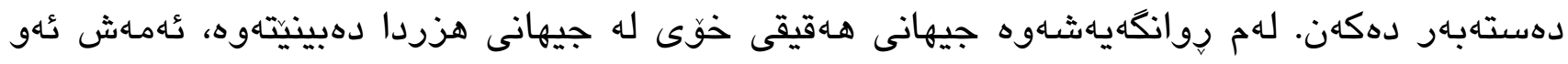

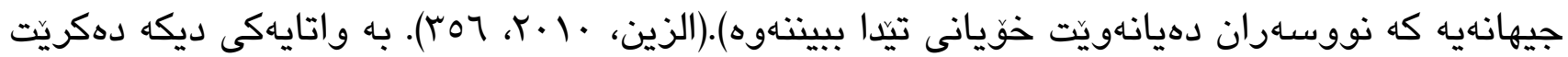

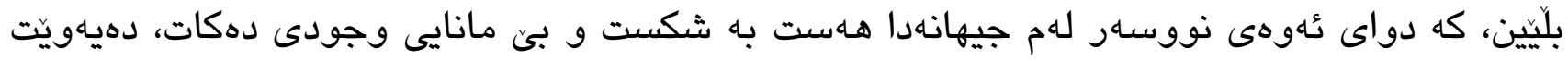

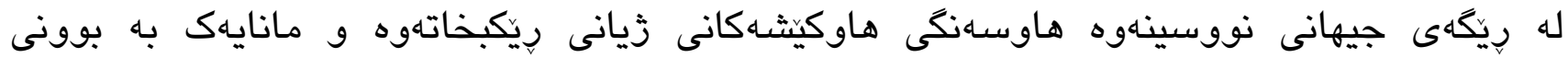

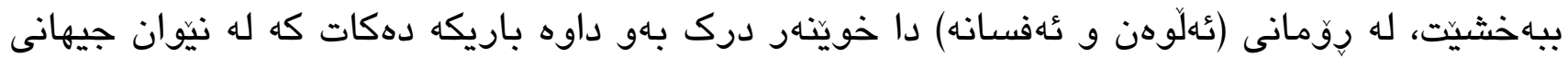
واقيع و جيهانى نموونهييا هـيه، ئهمه شواي ئهوهى روّمانتووس وهك يهكيك له ريكخستنه نهينييهكانى

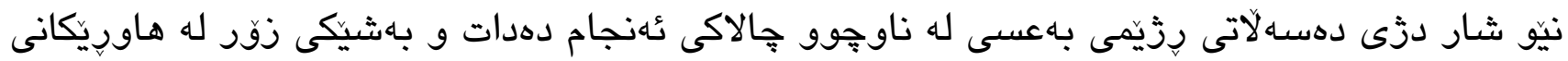

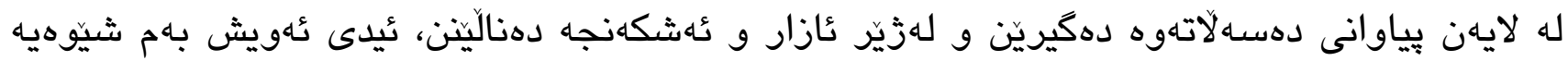

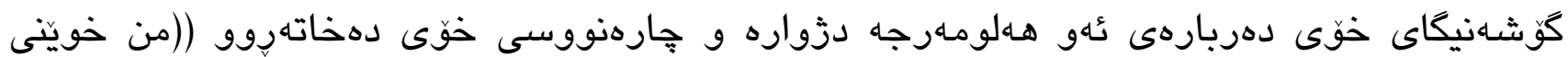

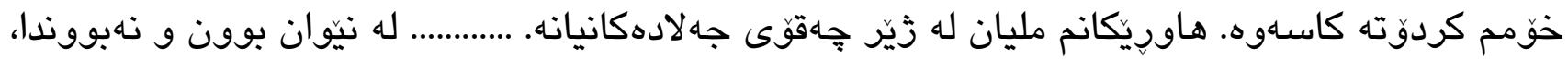

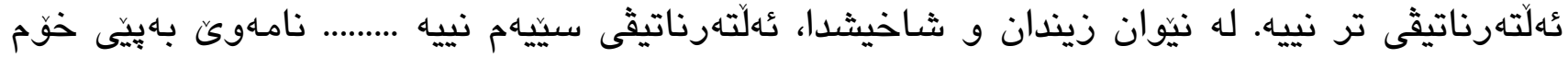

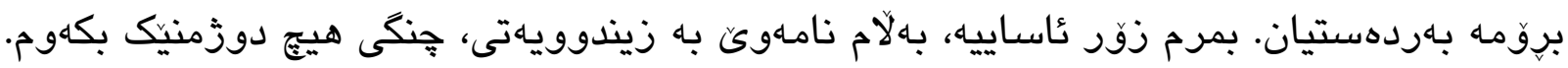

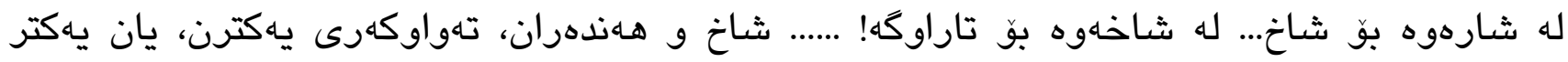

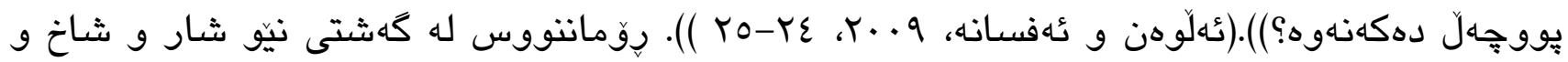
تاراوكهدا له كيزّاودايه و ناتوانيت خوّى وابهستهى جيهانى واقيع بكات، جونكه دهزانيت عئهو جيهانه سنوورداره، ناتوانيت خهونه وجودييهكانى ئهو وهك تاكيك بهينيتهدى، ئهو لهلايهك له غهامى تاكى

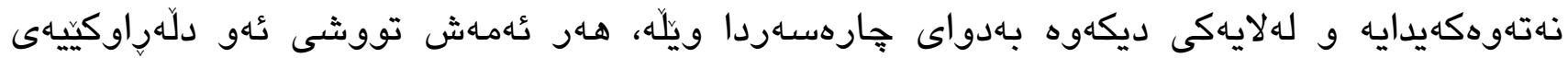
كردووه و دهيهويت له دهقيكى ئهدهبييدا جيهانيكى نموونهيى بونياد بنيت. بامانايهكى ديكه رِّمانتووس

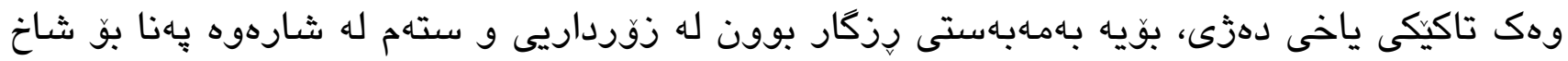
دهبات، به ئوميّدى وهدهستهينانى ئوقرهيى، بهلام هـاست دهكات شاخيش بِره له كؤسب و تهكَهره، دواجار

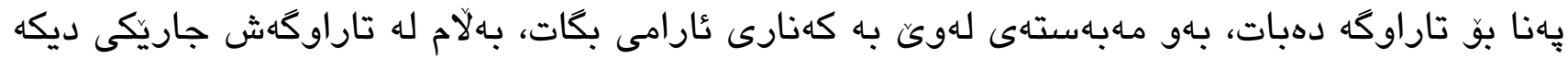

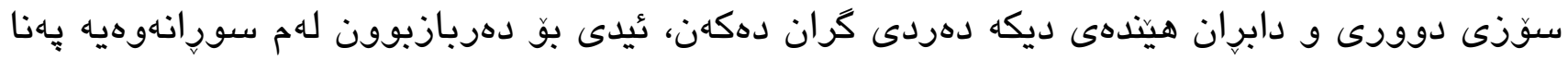




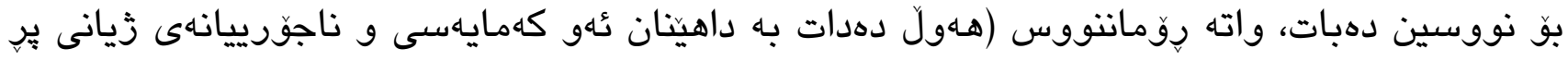

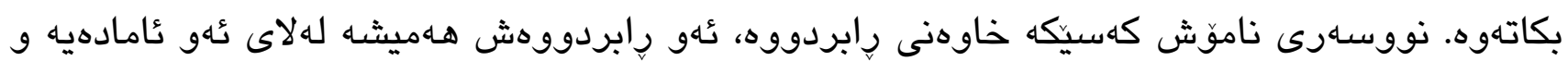

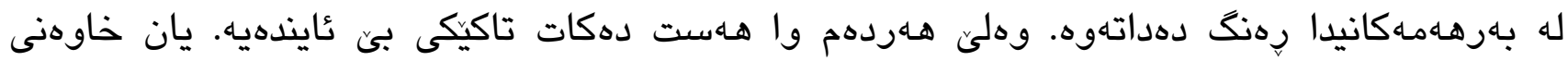
ئايندهيهكى تهماوى و نادياره. بوّيه ديسان هـهول دهدات قهرهبووى تايندهش بكاتهوه. واته كاريكّ بكات

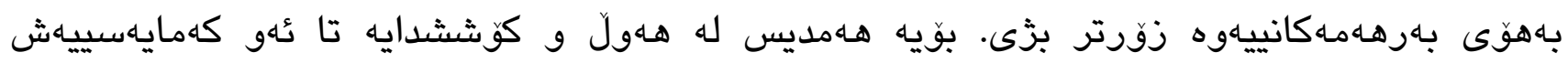

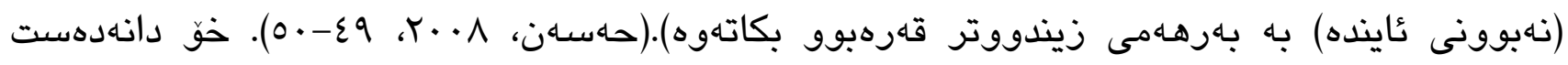

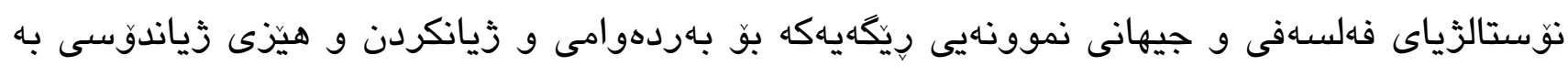
تاكى داهينهار دهبهخشيت، تاوهكو دووجارى شكست و نائوميّدى نهبيت، رِّمانتووس ويلّه له دوى

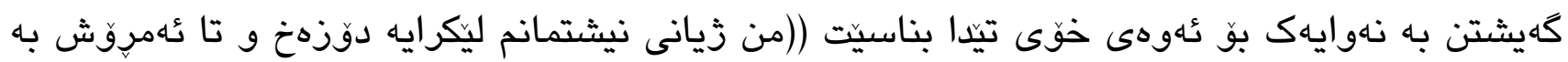

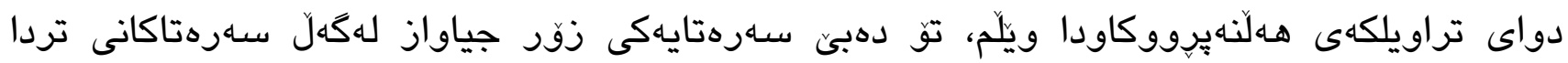

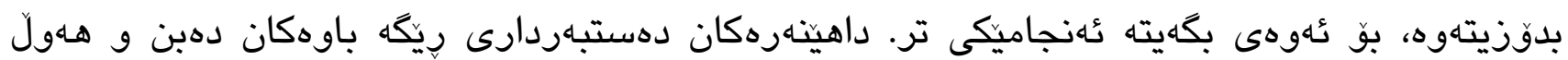

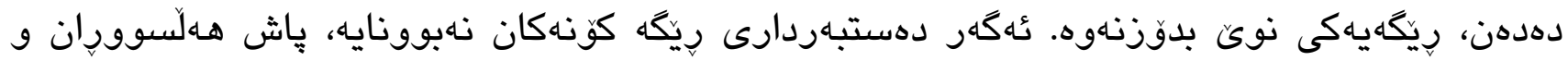

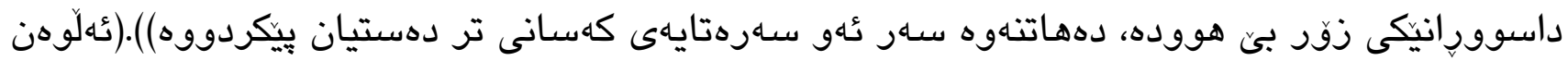

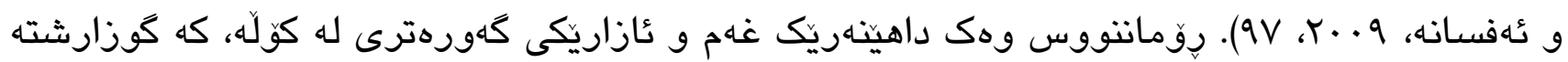

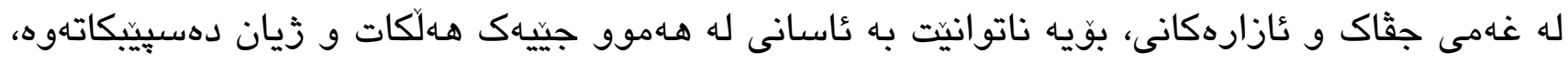

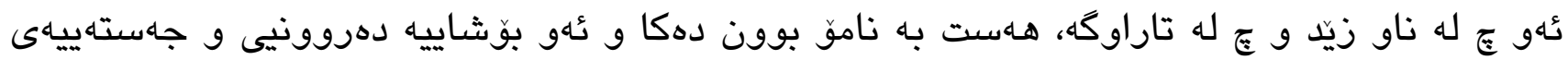
لهلاى روّمانتووس دروست بووه، زادهى غهمينكى وجووديى و كَردوونييه ((مروق بارمتهى دوو كونه،

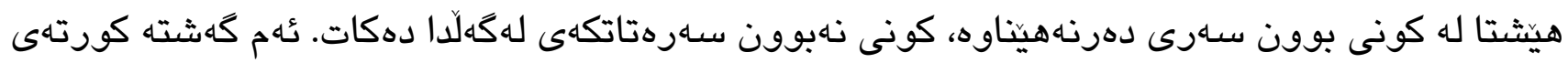

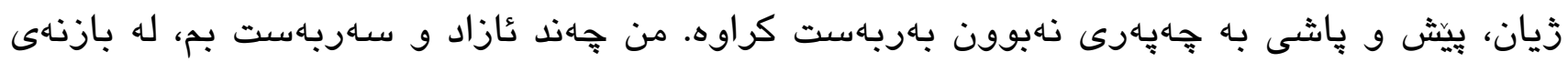

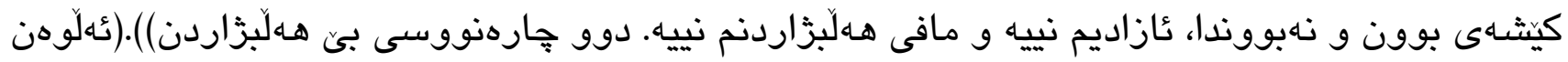

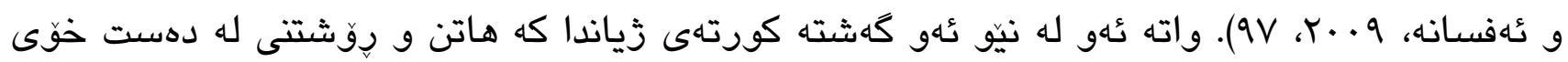
نييه، هـاست به بيَ دهسهلآتى و بئ هيزّى خوّى دهكات له وجووددا، ئازادى و سـربهستى ئهو سنوورداره، بوّيه ليَرهوه وهك مروّثيكى سهـكهش و ياخى هاوار دهكات و دهلّيت: ((من خاوهنى هيج

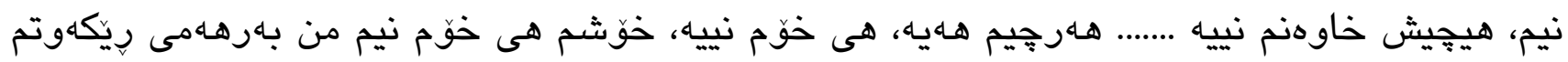

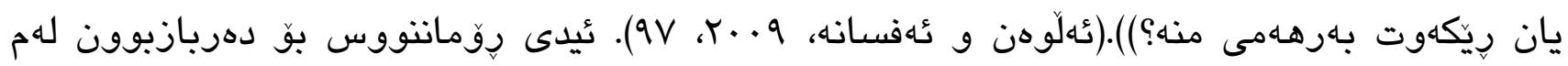
حالّهانه، واته له نيّو كَهتى كورتخايهتى ذيان و مردندا يهنا وهبهر نوّستالزّياى فهلسهـى دهبات، تاوهكو به هايهك بوّ بوونى خوّى للم كَهردوونه فراوانها بيينيتهوه. 


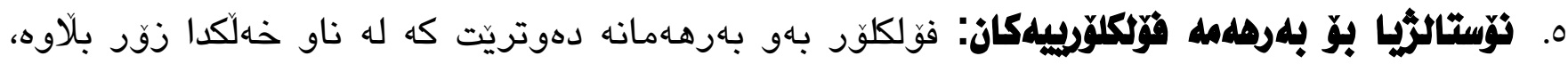

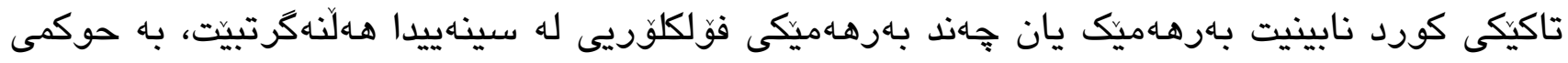

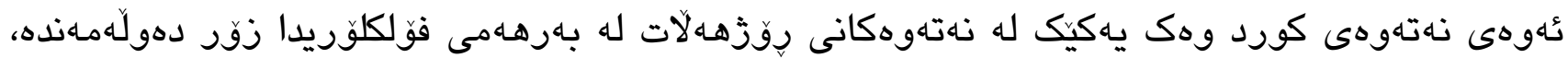

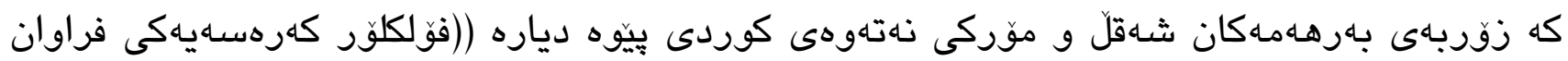

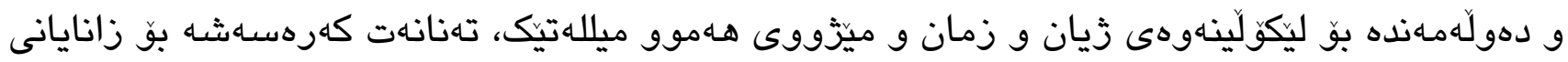

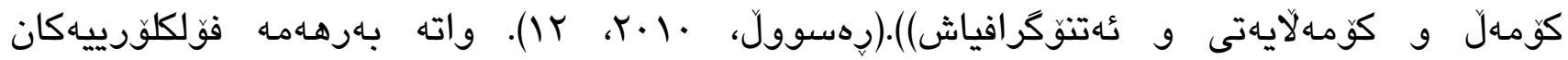

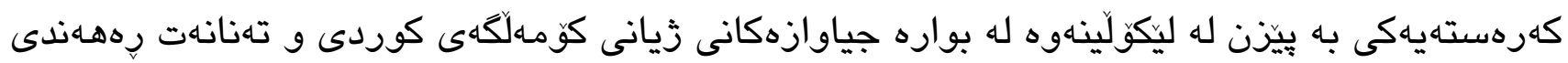

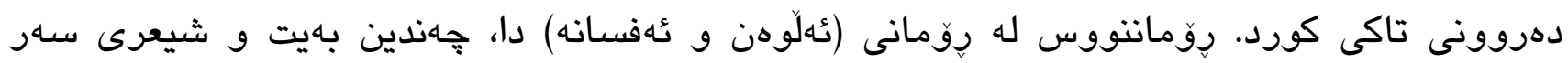
زارى خهلكى ناوجهى خانهقينى له نيو رِّمانهكدا تهوزيفكردووه، واته رِومانتووس كاتيك له ناموّييدا

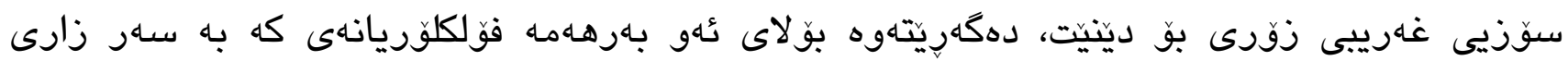

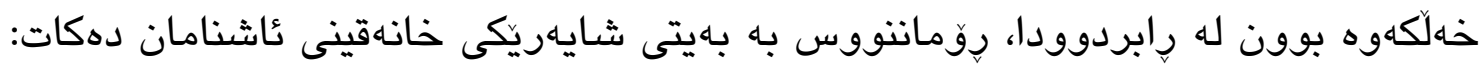

$$
\text { عاخر مردنه و هـر دور كال بكهى وهبهرزى كاوه جاوه }
$$

دوو تيّروانينى ناكوك بوّ زيان، يهكيكيان يا به دهولَهمهندى بذى، يان له كرياندا بمره).(ئلوهن و ئهفسانه، 9..r،

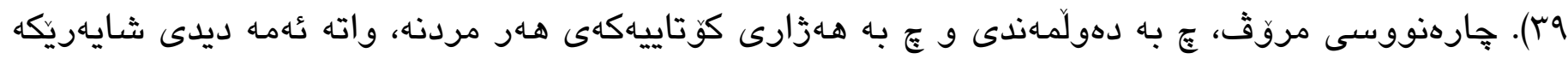

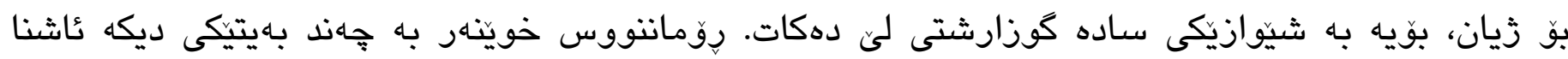

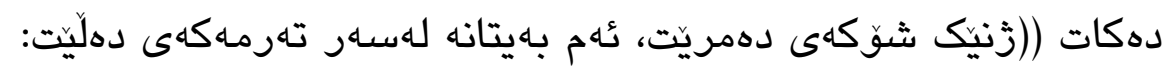

$$
\begin{aligned}
& \text { هاهر يه نهود يهكى تر } \\
& \text { كاوريّك نهور شهكى تر } \\
& \text { كئي سهك قهيان ئهو سهك كرت } \\
& \text { باوك هـيهار بِوخهل كرت } \\
& \text { زنهاكه هـلّس شويكَّه مرد } \\
& \text { شويكَهم مرد وهكو سمهور } \\
& \text { قرتكيگ كيرم هـم وسمهاو }
\end{aligned}
$$

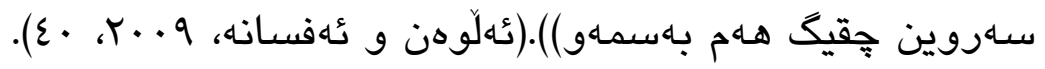

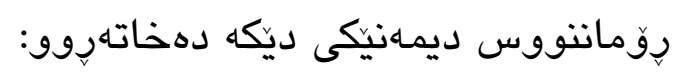




$$
\begin{aligned}
& \text { ((دويتتم، دويّته } \\
& \text { نقره كوته }
\end{aligned}
$$

حهت شووى كرديه و هيمرا دويته!

كاهمه شانازيى دايكانيى خانهقيييه بـ كجهانيانيانوه، حهوت شوو، يهك لهدواى يهك دهكهن و به كهى

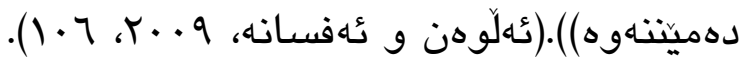

رِوماننووس بهم دوو بهيته شيعره كوتاييى به رِومانهكهى دههينيتيت:

(هارجهى ديت وهجههم شى وه سـهذهردا

هـاءرجى ماهوينى ها نهكوزهردا

كهس حالّى نهبى و هيج نهاماما

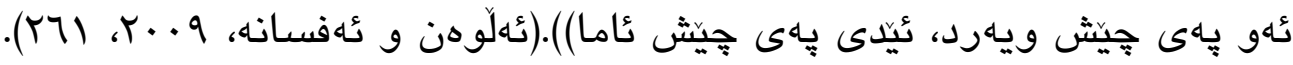

تُهو بابهته فوّلكوّرييانهى كه روّمانتووس تهوزيفى نيّو رِومانهكهى كردووه، هـهوويان به دياليكتى لورين و

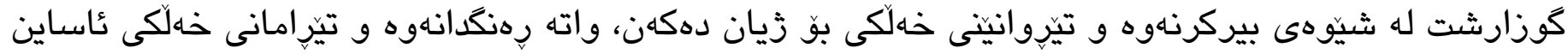
له بهرانبهر دياردهانى زيان. رِومانتووسيش تومارى كردوون، لهلايهك بوّ تُهوهى بيانياريزّيت لهلايهكى

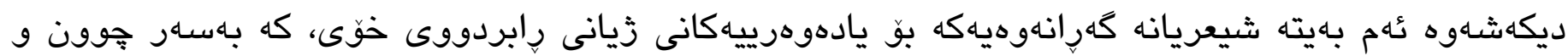
كهوتوونهاته نيّو ميَّووهوه.

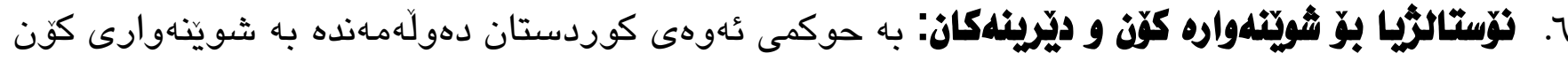

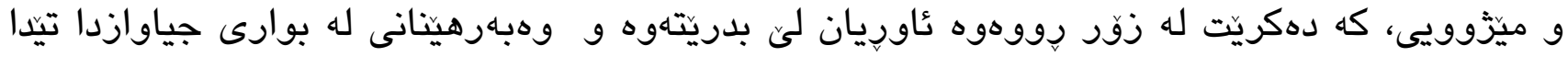

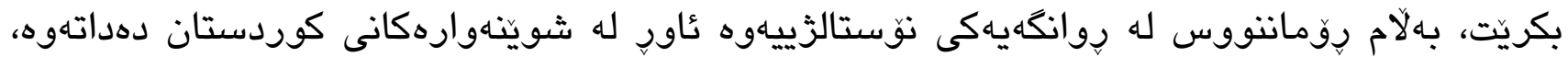

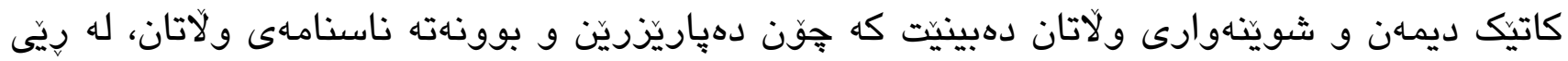

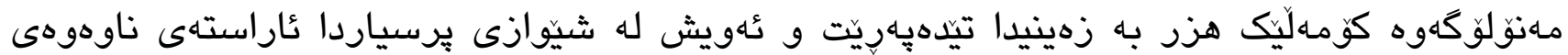
خَّى دهكات:

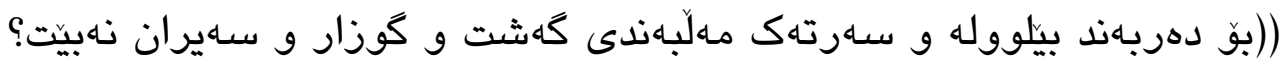

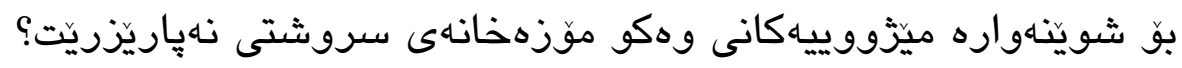
بوّ دهستى شيّويِنهار كرده دهستكردهكانى ويّران بكات؟

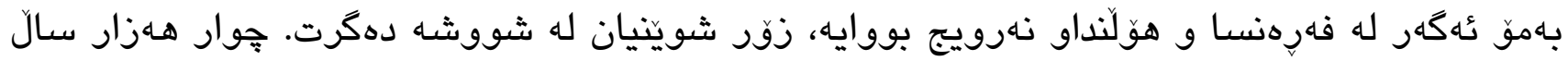

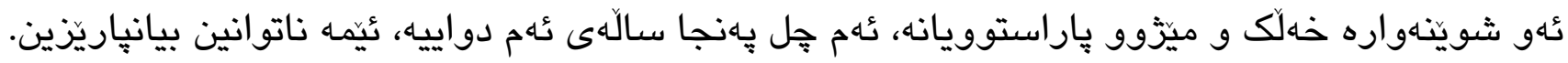




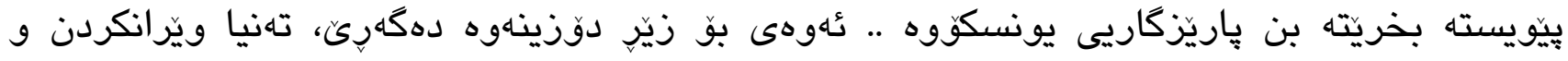

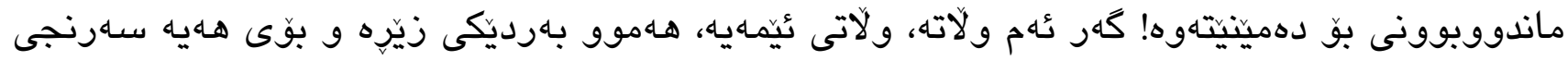

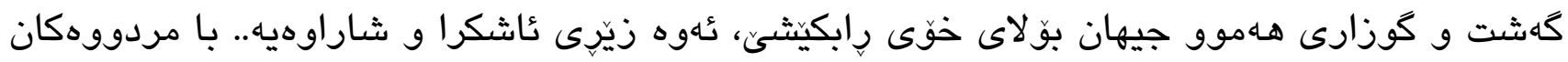

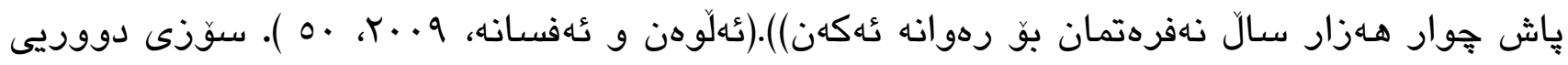

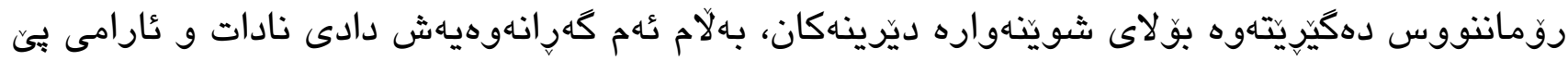

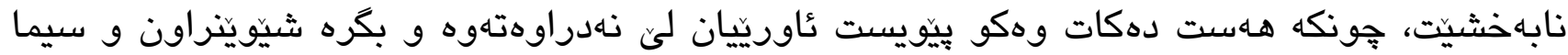
و سروشتيان تيكدراوه.

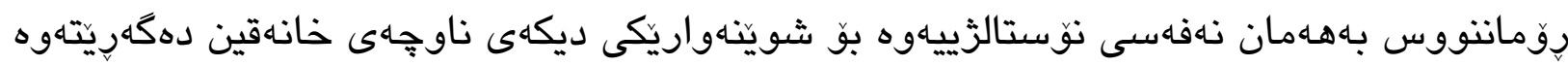

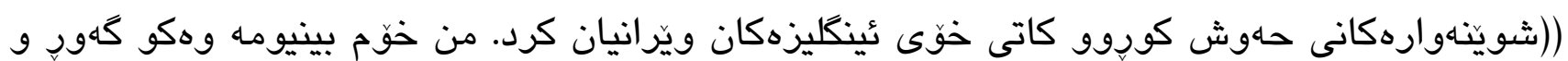
تاهويله بهكاريان دههينا. له بريتانيا و ئيرلهندهدا كوماهليك كيلى مهزن كراونهته موزهخانه.. ولّاتى ترى

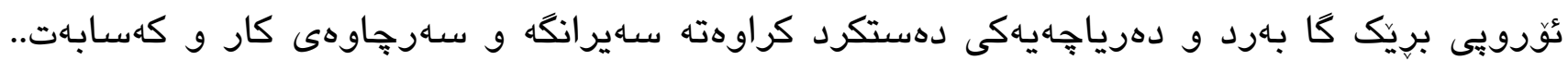

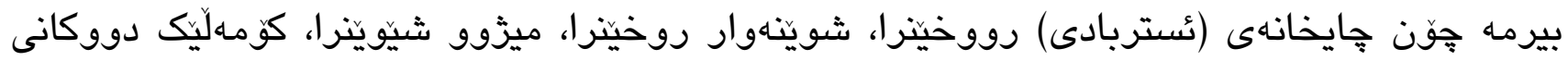

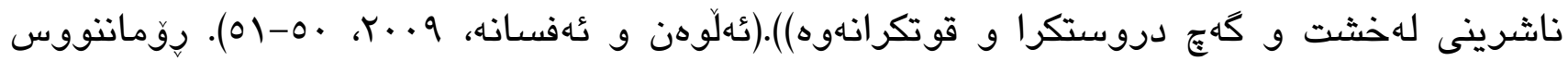
دهكهويته بهراوردهوه له نيّان شوينّاوارى ولآته ثُهورويييهكان و شوينّهوارهكانى كوردستاندا، كه

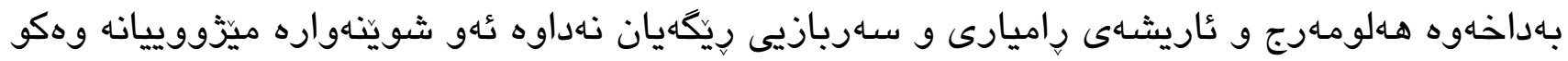

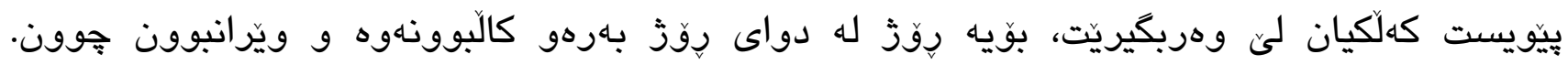
روّمانتووس ويلّه بهدواى رهمزيكدا تابييته ناسنامهى شارهكهى، جونكه ((هـه شاريّك له جيهاندا

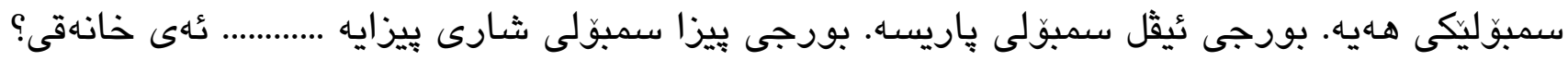

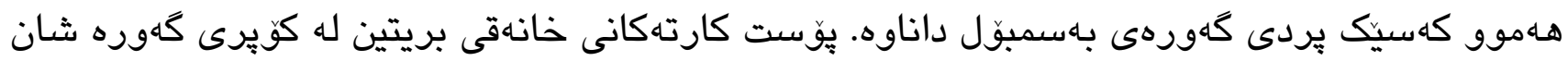

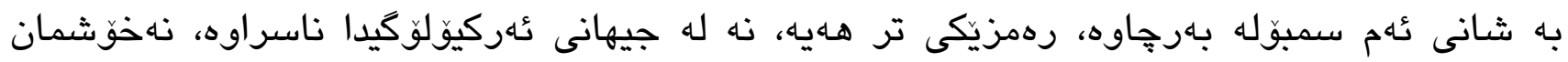

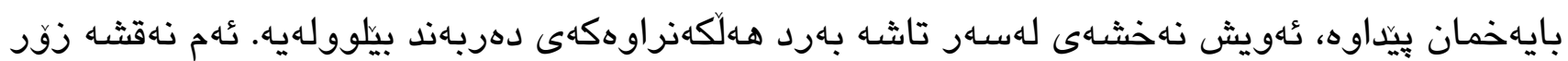

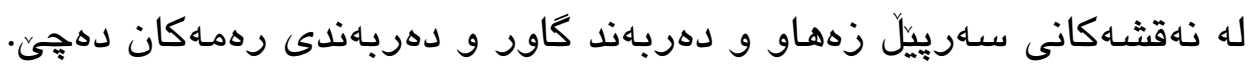

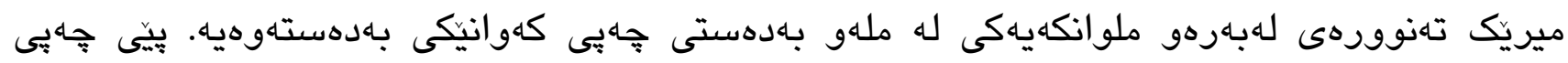

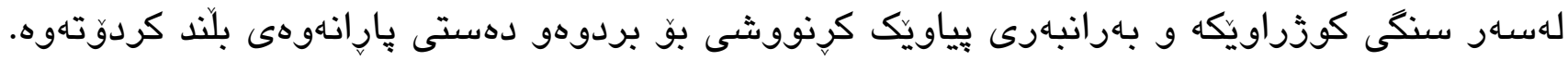

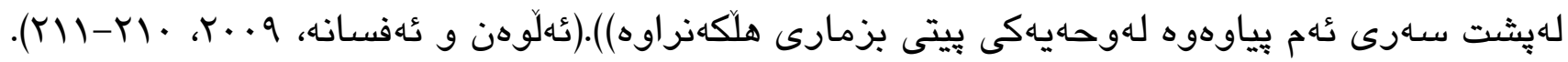

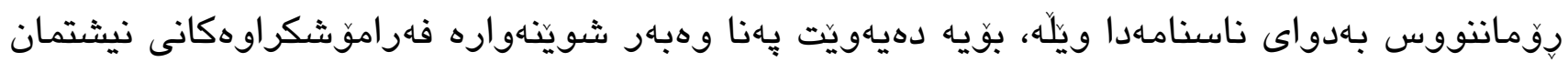

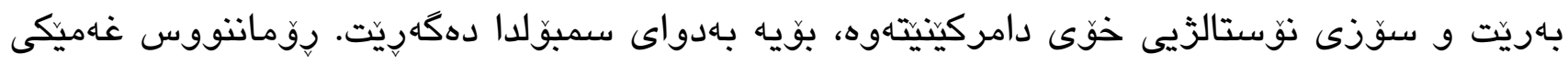

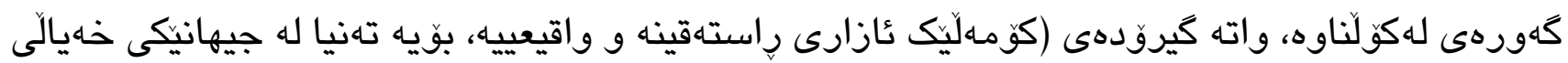
و نوستالزييانهدا ترووسكاييهك بو حهسانهوه و رهواندنهوهى غهمهكانى دهدوزيتهوه).(ئحمـدزاده، 


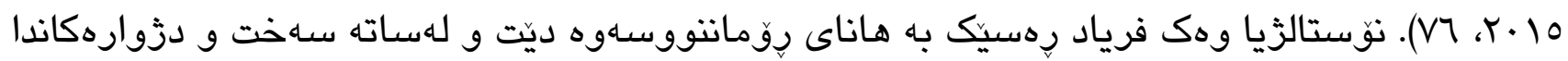

$$
\text { دهرديى دووريى و دابرانى تيمار دهكات. }
$$

\section{ئلمنجاملكان}

ا. نوستالزيا وهك دياردهيهكى دهروونى له دنياى رِومانى (ئهلوهن و ئهفسانه) دا ئامادهييهكى بهرجاوى

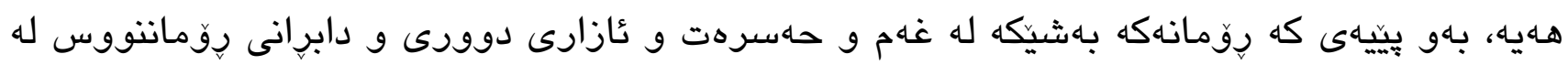
نيشتمان و زيانكردن له تاراوكهدا.

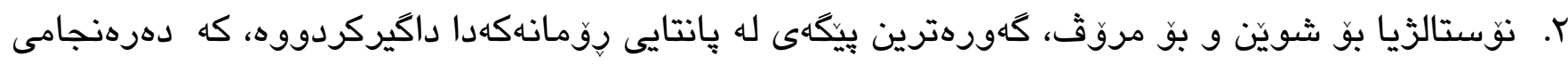

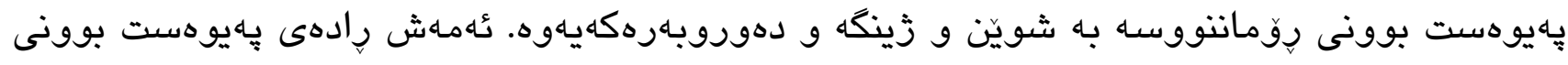

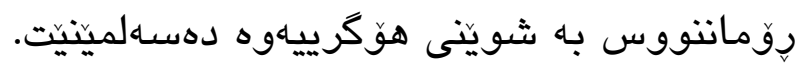

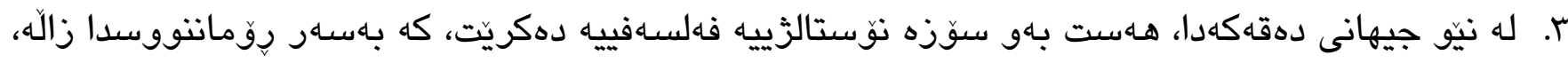

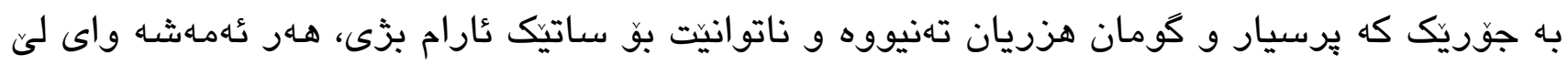

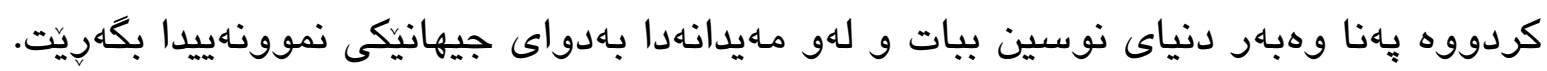

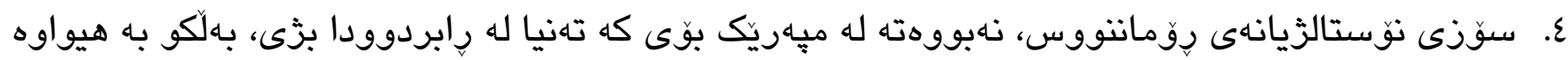

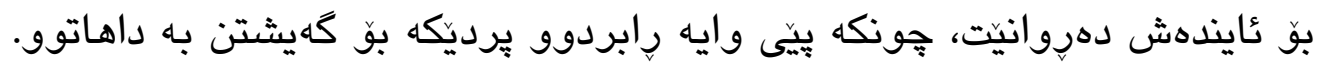




\title{
Nostalgia in the Novel (ALWAN and AFSANE) by Mamosta Jaafar
}

\author{
Awara Kamal Saleh \\ Building \& Construction Department, Erbil Technology College, Erbil Polytechnic \\ University, Erbil, Kurdistan Region, Iraq. \\ E-mail: awara.saleh@epu.edu.iq
}

\begin{abstract}
:
Nostalgia for the past is a phenomenon that is present in most members of society, but its impact varies from one person to another, and nostalgia appears in humans in cases of distance and alienation from the homeland, in other words when a person is uprooted from his roots and spends his life in the diaspora, and here nostalgia for the past dominates his thinking and reflections. And nostalgia leaves a deep impact on the author. That is why the book resorts to the world of writing to get rid of the pain of alienation. And back again to the world of childhood. With this hope, they can interrupt for a moment from the present time and return to the time of youth. Here, they can make a magical trip to the past in order to give their souls and themselves a moment of calm and stability. In this research, we have tried to embody the types of nostalgia in the novel (ALWAN and AFSANE).
\end{abstract}

Key words: Nostalgia, Past, Deserted, Homesick, Home. 


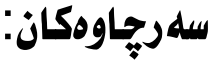

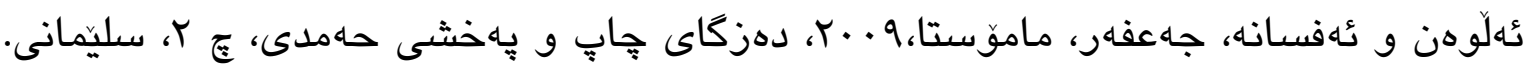

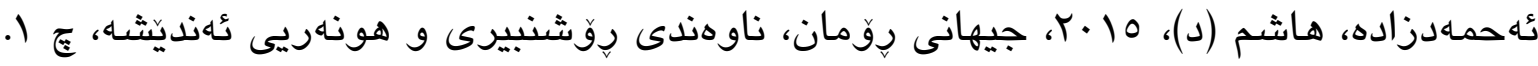
ئهوهد، نهوزاد ئهممهد (د)، 10 • r، فهرهـنكى زاراوهكانى ئهدهب و زانسته مروقايهتييهكان، ناوهندى غهزهلنووس بو جاب و بلاّوكردنهوه، ع 1.

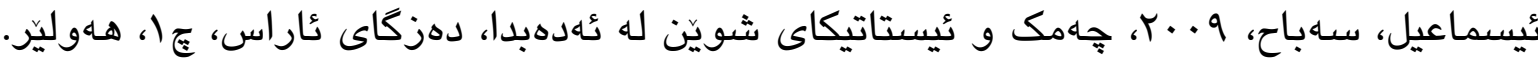

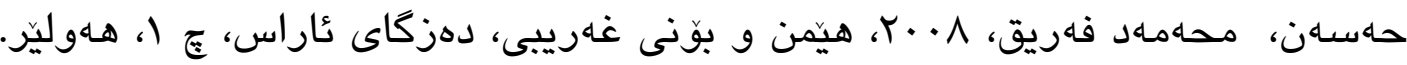

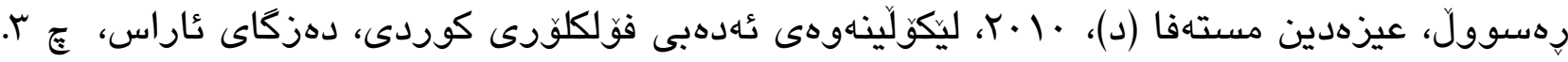

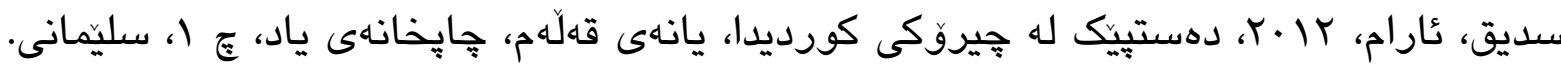

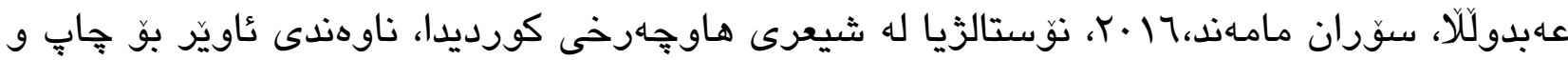

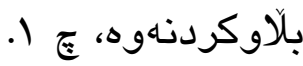

ابراهيم، علي(د)، r..r، الزمان و المكان في روايات غائب طعمة فرمان، الاهالي للطباعة و النشر والتوزيع، ط

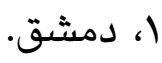

الحربي، صيتة علي عواد، إ·، الحنين للوطن في شعر الجواهري: دراسة فنية، رسالة ماجستير، كلية الآداب و العلوم، جامعة الشرق الأوسط.

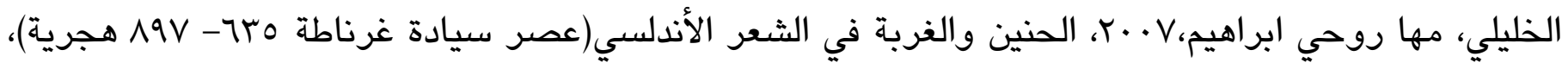
رسالة ماجستير، كلية دراسات العليا، جامعة النجاح الوطنية، نابلس، فلسطين. 
الزين، محمد موسى البلولة، • • ب، الاغتراب و الحنين في الشعر المهجري، اطروحة دكتوراه، كلية الآاب / قسم اللغة العربية، جامعة الخرطوم.

سالم، إسلام سعدي، \\•r، النوستالجيا: المصطلح الطبي الذي انتهى إلى حالة شـاعرية، https://manshoor.com/society/nostalgia-illness-and-meaning

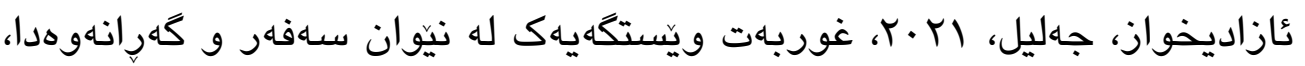
.https://www.haremnews.com/details/18415

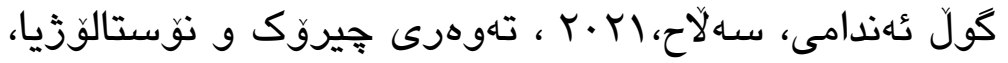
.http://hemin.dk/DAQIKURDI/2009/TA_chirokWnwstalwzhiya_SGA.htm 